\title{
Long-term river terrace sequences: Evidence for global increases in surface uplift rates in the Late Pliocene and early Middle Pleistocene caused by flow in the lower continental crust induced by surface processes
}

\author{
R.Westaway \\ 16 Neville Square, Durham DH1 3PY, England. \\ Manuscript received: November 2000; accepted: February 2002
}

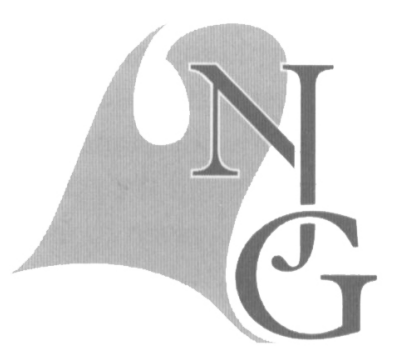

\begin{abstract}
Long-term river terrace sequences reveal that many regions have uplifted by several hundred metres since the Middle Pliocene. They indeed provide evidence of a global increase in uplift rates in the Late Pliocene, followed by a calm period then a renewed increase around the Early-Middle Pleistocene boundary. It is suggested that this uplift pattern has resulted from thickening of the continental crust caused by flow in the lower crust which has been induced by cyclic surface loading caused by growth and decay of ice sheets and the associated global sea-level fluctuations. Observed uplift histories are modelled using a technique which incorporates increases in the strength of forcing of this process caused by step changes in the intensity of glaciations starting at $\sim 3.1, \sim 2.5, \sim 1.2$, and $\sim 0.9 \mathrm{Ma}$.
\end{abstract}

Key words: Quaternary, glaciation, river terraces, uplift, surface processes, lower-crustal flow

\section{Introduction}

Whether the Earth's surface has uplifted systematically during Late Cenozoic time has long been debated. Decades ago, studies noted that land surfaces indicative of prolonged stability have become incised by river gorges during the Neogene and Quaternary by hundreds of metres (e.g., Du Toit, 1933; King, 1955; De Sitter, 1952; Flint, 1957; Holmes 1965; Damon, 1971). These early studies made the common sense assumption that this incision has required uplift of these land surfaces relative to sea level. In some regions the Earth's surface is of course uplifting due to crustal thickening caused by convergent plate motions. However, until recently no satisfactory physical mechanism was known that could account for uplift of this order away from plate boundaries (see below).

Molnar \& England (1990) suggested that previous studies had mistaken increases in relief during the
Quaternary, caused by increased rates of denudation in response to the changing climate, for increases in the mean altitude of the Earth's surface. Gilchrist et al. (1994) and others have also noted that rates of gorge incision do not necessarily relate simply to uplift rates of interfluves. Any use of altitudes of river terraces, deposited during gorge incision, to determine a region's uplift history must thus take care to justify its assumptions.

The continental crust consists of an upper, brittle, layer, overlying a plastic layer which behaves like a viscous fluid on geological time scales. It was established many years ago that the boundary between these layers is thermal - not compositional - being the depth at which the temperature is $\sim 350^{\circ} \mathrm{C}$ (e.g., Sibson, 1982; Kusznir \& Park, 1984). The viscosity of the lower crust at a given temperature is difficult to determine, because its composition and physical state (whether typically isotropic or possessing a fabric 
caused by earlier deformation) are unclear. As was shown by Westaway (1998), another important factor is the nature of the extrapolation used to relate laboratory rock mechanics data obtained at high temperatures and strain rates to the much lower temperatures and strain rates typically present in the lower continental crust. Westaway's (1998) results established the likelihood that the effective viscosity of the lower continental crust (the viscosity which an isoviscous layer would need to have to produce the same flow rate in response to a given pressure gradient as is observed in the real lower crust with a temperature-dependent viscosity) can be as low as $\sim 10^{18}-10^{19} \mathrm{~Pa}$ s.

Like any other fluid, the lower crust will flow in response to applied pressure gradients. These may result from lateral variations in loading at the Earth's surface. Mitchell \& Westaway (1999) showed by simple first-order calculations that with such low viscosities in the lower crust, steady rates of erosion and sedimentation can cause pressure gradients in the lower crust which are sufficient to cause significant relief to develop. However, surface loads in some localities are not steady: they may be cyclic, caused by the growth and decay of ice sheets or the associated variations in global sea-level; or transient, caused by changing rates of denudation or sedimentation. Crustal deformation caused by lower-crustal flow induced by surface processes is called 'atectonic' deformation (e.g., Kaufman \& Royden, 1994), in contrast with tectonic deformation that is caused by plate motions. Because the lower crust is weaker than either the brittle layer above it or the mantle lithosphere or asthenosphere below it, flow in it provides an important mechanism for isostatic compensation. However, as already noted, the top of the lower crust is a thermal - not a compositional - boundary, which is maintained at $\sim 350^{\circ} \mathrm{C}$. As a result, denudation will cause the base of the brittle layer to advect down relative to the rock layers present at mid-crustal depths: transferring crust from the plastic to the brittle régime; and sedimentation will conversely transfer crust from the brittle to the plastic régime. This complexity means that developing internally-consistent methods for modelling transient surface processes is extremely difficult.

Molnar \& England (1990) ignored lower-crustal flow in their isostatic response calculations. Mitchell \& Westaway (1999) showed that a localised increase in the denudation rate can reduce the pressure at the base of the brittle layer sufficiently to cause an influx of lower crust which vastly outweighs the loss by denudation at the surface. As a result, the crust can experience dramatic net thickening, accompanied by surface uplift, in localities with increased rates of denudation. The main conclusion by England \& Molnar
(1990), that increased rates of denudation will create increased relief but maintain a near constant (but slightly decreasing) mean surface altitude, is thus mistaken: increased rates of denudation can instead cause significant increases in mean surface altitude.

Regardless of the role of transient changes in denudation rates, it is evident that many major rivers which have incised gorges and created terrace sequences drain regions with negligible denudation rates (e.g., Maddy, 1997, 1998; Westaway, 2001; Westaway et al., 2002). As a result, an alternative physical mechanism can be considered, in which the observed surface uplift results from lower-crustal flow induced by cyclic surface loading.

Fig. 1 summarises such a model. This model is explained qualitatively here (see Fig. 1 caption). Its algebraic form is omitted due to length limitations, but is given in full by Westaway (2001) and Westaway et al. (2002). It uses an approximate analytic solution to the advective diffusion equation for heat flow, which is solved for a sequence of $25 \mathrm{ka}$ time steps, to determine the advection of the base of the brittle layer and the resulting pressure perturbation. This result is then used in a simultaneous solution of the equations for conservation of lower-crustal mass and pressure equilibrium at the end of each loading cycle, to determine the time-averaged uplift rate during that cycle. This solution incorporates the effect of offshore water loading, which contributes to maintaining the modified equilibrium state in which the offshore crust has experienced net thinning to supply the net accumulation of lower crust beneath the land. The resulting predicted uplift history of the land area is then determined by numerical integration.

\section{Modelling strategy}

Modelling using this method requires knowledge of $z_{b}$ and $z_{w}$, the depths of the top and base of the lower crust, and $u$ and $\kappa$, its geothermal gradient and thermal diffusivity. The depth $\mathrm{z}_{\mathrm{i}}$, where lower-crustal flow is concentrated, is roughly nine tenths of the way between $z_{b}$ and $z_{w}$ (Westaway, 1998). The equations used to predict uplift rates and histories are given in Westaway (2001).

Modelling follows the strategy of Westaway (2001): $\kappa$ is fixed at $1.2 \times 10^{-6} \mathrm{~m}^{2} \mathrm{~s}^{-1} ; \mathrm{z}_{\mathrm{b}}, \mathrm{z}_{\mathrm{w}}$, and $\mathrm{u}$ vary. Surface uplift is assumed to result from the superposition of forcing components, caused by the process in Fig. 1, with different magnitudes and start times. As in Westaway (2001), this forcing is assumed to comprise five such components, each characterised by the parameter $\Delta \mathrm{T}_{\mathrm{e}}$. 


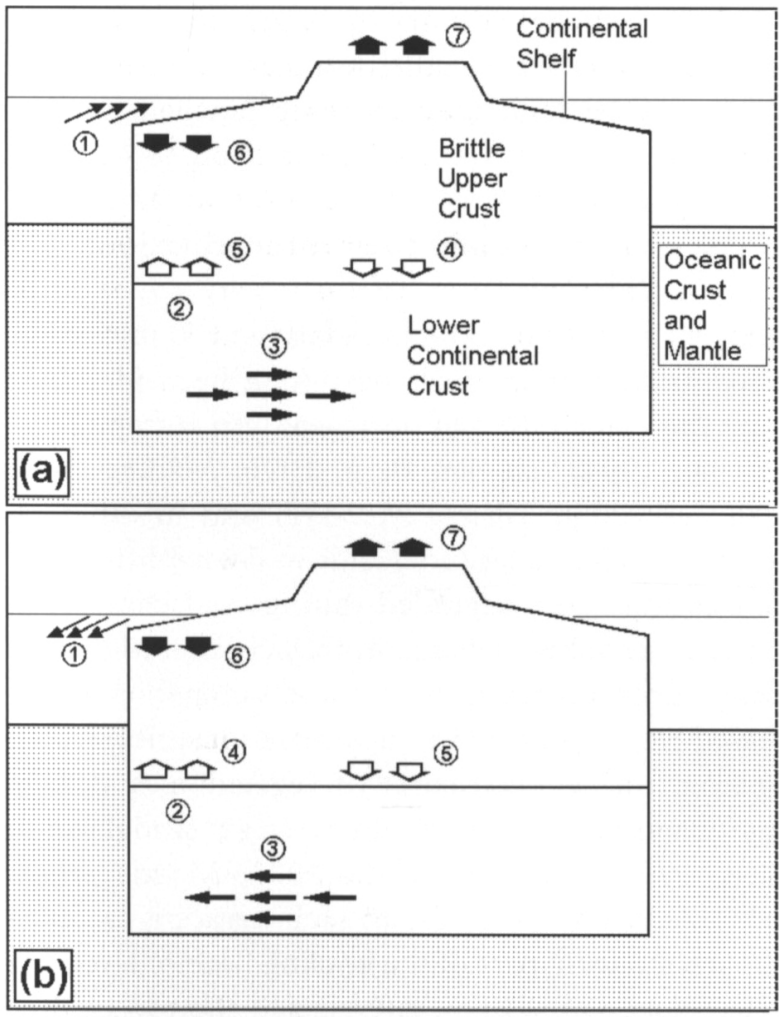

Fig. 1. Summary of the model. Just above the Moho, the lower crust will have a lower temperature offshore than onshore, due to thermal conduction: the offshore crust is thinner than the onshore crust, but the mantle lithosphere is assumed to have the same thickness in both localities. (a) During interglacial marine highstands, the rise in sea level (1) causes an increase in the pressure at the base of the brittle layer beneath the offshore shelf (2). This causes a landward pressure gradient, which drives relatively cool lower crust from beneath the shelf to beneath the land (3). This inflow of relatively cool lower crust perturbs the geothermal gradient beneath the land, causing the base of the brittle layer to move downward relative to the land surface (4). The effect of earlier flow

\section{Forcing chronology}

$\Delta \mathrm{T}_{\mathrm{e}}$ provides a measure of the temperature contrast, near the base of the crust, between the study region and the adjoining source of the lower crust which causes the crustal thickening that supports its surface uplift, scaled by the ratio of dimensions of the regions. The actual temperature contrasts are unknown, as are the overall dimensions of the sources of lower crust and the regions which are uplifting. As a result, like in Westaway (2001), $\Delta T_{e}$ for each phase of uplift forcing is treated as a free parameter, whose value is adjusted to match the available observations.

The first phase of forcing included, starting at a nominal time of $t_{01}=18 \mathrm{Ma}$, causes very slow uplift throughout the Late Miocene and Pliocene. Westaway (2001) suggested that this slow uplift was forced by cyclic loading of the continental shelf by fluctuations in the global sea-level caused by the growth and decay of warm lower crust to beneath the offshore shelf causes a corresponding perturbation to the offshore geothermal gradient, which causes the base of the brittle layer to move upward relative to the sea floor (5). Taking account of the need to balance overall crustal volume within a closed system, the overall isostatic response to these processes requires the sea floor of the shelf to adjust downward, causing net thinning of the offshore crust and deepening of the shelf sea (6), and thickening of the crust beneath the land, causing the land surface to uplift (7). (b) During glacial marine lowstands, the fall in sea level (1) causes a decrease in the pressure at the base of the brittle layer beneath the offshore shelf (2). This causes a seaward pressure gradient, which drives relatively warm lower crust from beneath the land to beneath the shelf (3). This inflow of relatively warm lower crust perturbs the geothermal gradient beneath the shelf, causing the base of the brittle layer to move upward relative to the sea floor (4). The effect of earlier flow of cool lower crust to beneath the land causes a corresponding perturbation to the onshore geothermal gradient, which causes the base of the brittle layer to move downward relative to the land surface (5). Taking account of the need to balance overall crustal volume within a closed system, the overall isostatic response to these processes requires the sea floor of the shelf to adjust downward, causing net thinning of the offshore crust and deepening of the shelf sea (6), and thickening of the crust beneath the land, causing the land surface to uplift (7). The resulting relief is dynamically maintained by the requirement for overall pressure equilibrium at the base of the brittle layer. This equilibrium state is assumed to be maintained pointwise: the flexural rigidity of the brittle upper crust is ignored, as many studies (e.g., Westaway, 1993a) indicate this is very low such that if required the brittle can warp on a spatial scale of a few kilometres (see, also, Westaway et al., 2002).

This figure illustrates this equilibrium for a notional small isolated island in continental crust where the growth of topography is unaccompanied by the development of a lower-crustal 'root' - the excess mass is instead supported by the mantle lithosphere. Given the magnitude of the flexural rigidity of the mantle lithosphere, the spatial scale of loading in most examples in the present study requires the downward deflection of the mantle lithosphere and the resulting creation of a lower-crustal root. However, the principle of the calculation is unaffected (but see text for further discussion).

of the Antarctic ice sheet, which already existed in the Miocene.

The timings of other phases of uplift forcing also follow Westaway (2001). The second phase, starting at $\mathrm{t}_{\mathrm{o} 2}=3.1 \mathrm{Ma}$, represents forcing due to ice loading effects and sea-level fluctuations following the start of upland glaciation in the northern hemisphere around 3.1 Ma. The third phase, starting at $t_{03}=2.5 \mathrm{Ma}$, represents additional forcing due to enhanced ice loading effects and sea-level fluctuations following the start of lowland glaciation in the northern hemisphere around $2.5 \mathrm{Ma}$. The fourth phase, starting at $\mathrm{t}_{\mathrm{o} 4}=1.2$ $\mathrm{Ma}$, represents additional forcing due to enhanced ice loading effects and sea-level fluctuations following the buildup in scale of ice sheets at glacial maxima around oxygen isotope stage 36 , revealed in some oxygen isotope records (e.g., Shackleton et al., 1990). The final phase, starting at $t_{05}=0.9 \mathrm{Ma}$, represents additional forcing by their further growth in scale start- 
ing in oxygen isotope stage 22 (e.g., Mudelsee \& Schwartz, 1997).

\section{Calculation of Uplift from Incision}

In general, no simple relationship exists between the incision of a gorge and the uplift of the adjacent land surface (e.g., Gilchrist et al., 1994; Whipple et al., 1999). However, if a river returns to the same gradient at each pause in incision (i.e., during each interglacial), thus establishing a new quasi-equilibrium profile which is the same as its previous profiles, and erosion rates of interfluves are negligible, then - as previously argued (Maddy et al., 2001; Westaway, 2001; Westaway et al., 2002) - incision can provide a measure of the uplift of the land surface forming the interfluves. The requirement for negligible erosion of interfluves arises because, if interfluves are eroding significantly, the isostatic response will cause the crust beneath the interfluves to uplift, simply in order to compensate the erosion. As a result, the river gorge will also be uplifted. Depending on geometrical factors, such as the distance of the study locality from the edge of the uplifting region (and thus, from localities which are not uplifting, and so remain in touch with base level) the river may or may not incise further in response to this uplift of its gorge.

The validity of the assumption that equivalent quasi-equilibrium profiles develop after each climate cycle can be argued for many river terrace sequences given the near uniform thicknesses and parallelism of deposits from each cycle. The validity of the assumption of negligible erosion rates of interfluves can be argued for many major rivers via first order calculations of sediment budgets (e.g., Ahnert, 1970; Milliman \& Syvitski, 1992; Westaway, 2001). This reasoning is supported by observations that much of the area of interfluves may be covered by apparently intact terrace deposits, or thin layers of weathered rock derived from prolonged weathering of Tertiary sediments, which have not been removed by erosion.

Subject to these assumptions both being satisfied, the incision between equivalent parts of successive climate cycles will equal the uplift of the adjoining land surface, provided the downstream channel length has remained unaltered. If, instead, a new quasi-equilibrium profile, equivalent to the previous one, develops after the downstream channel length has increased, then the incision will underestimate the uplift of the adjoining land surface. Corrections for such channel lengthening (or shortening) are necessary to model the Maas and Thames terrace sequences (Westaway, 2001; Westaway et al., 2002), but are unnecessary for most other river terrace sequences ex- amined here. The summaries presented here of the uplift histories of these other terrace sequences will in due course be reinforced by more detailed publications.

\section{Terrace sequences and their interpretation}

Sequences of gravel terraces rising to $\sim 100 \mathrm{~m}$ or more above modern river levels have long been identified along the major rivers of north-western Europe (e.g., Antoine, 1994; Van den Berg, 1996; Maddy, 1997; Bridgland, 2000; Westaway, 2001) and in other regions at temperate latitudes. It is well-established that these gravels have aggraded during cold climate cycles, as river valleys change from incisional to depositional environments due to the combination of increased rates of erosion in upstream localities, resulting from the reduced cover of vegetation, and from large-magnitude seasonal flows (e.g., Bridgland \& Allen, 1996; Schumm et al., 2000; Maddy et al., 2001). As a result, the base of each terrace is assumed to mark the early part of the cooling limb of a climate cycle, shortly after each interglacial; the top of each terrace being assumed to mark the early part of the following warming limb, shortly after the subsequent glacial maximum.

\section{The Maas, southeastern Netherlands}

The Maas around Maastricht in the Netherlands (Fig. 2) has yielded the most complete published long-term river terrace record anywhere in the world (Figs. 3, 4), with 31 terraces, many independently dated (Van den Berg, 1996; Van den Berg \& van Hoof, 2001). The resulting uplift history has been modelled by Westaway (2001) (Fig. 5).

\section{The Rhine, western Germany}

In contrast with the nearby Maas, no more than 16 terraces are recognised along any reach of the Rhine (Fig. 2). Their timing of formation is also problematic, as different reaches have been studied by different people who have devised different chronologies. Westaway (2001) thus proposed a new chronology which appears to satisfy the available evidence. The altitudes of individual terraces above river level increases southward from the lower Rhine embayment into the Middle Rhine gorge (Fig. 6), where uplift has been up to three times faster than around Maastricht (Figs. 7, 8). Westaway (2001) suggested that the heating effect in the uppermost mantle accompanying this crustal thickening may account for this region's Quaternary volcanism. 


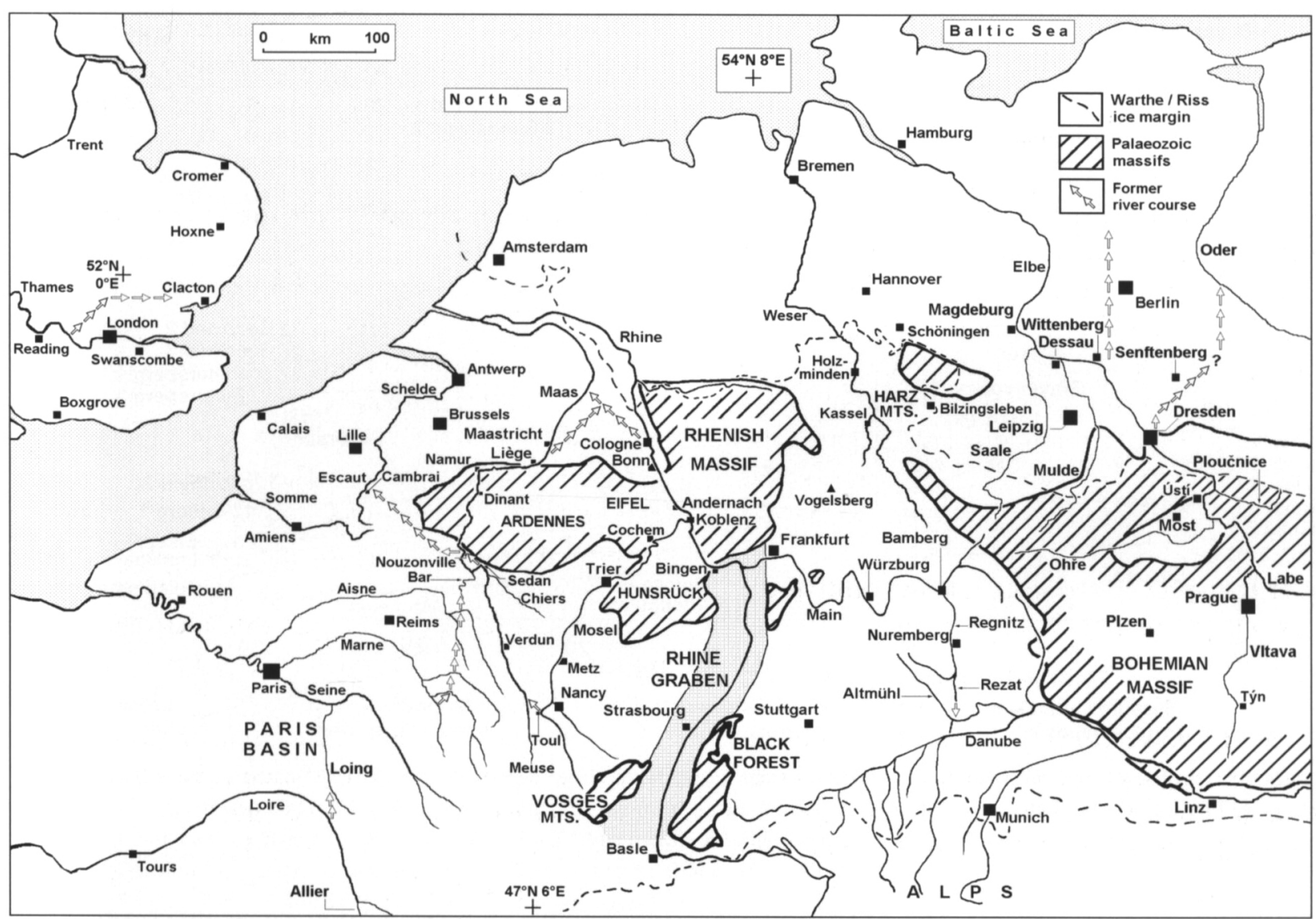

Fig. 2. Map of western and central Europe, showing the locations of most of the river terrace sequence which are modelled in this study. Note the east-west-trending 'corridor', $\sim 200$ to $\sim 400 \mathrm{~km}$ wide, between localities which have been covered by Alpine or Scandinavian ice sheets, where these terrace sequences are located. Adapted from Westaway (2001), (Fig. 1).

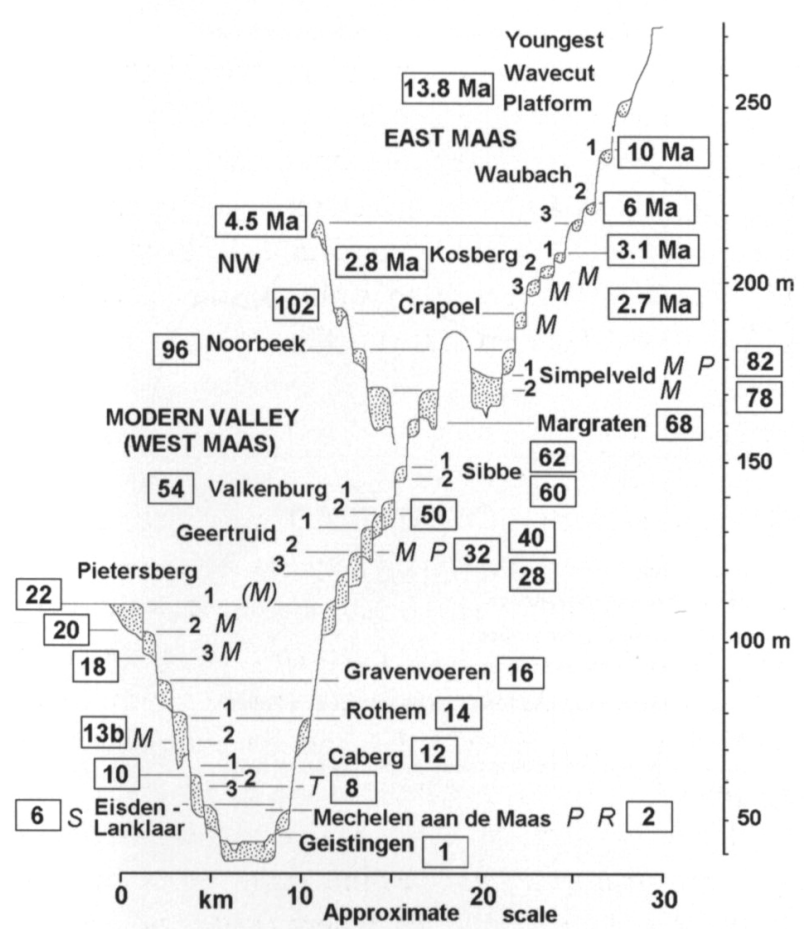

Fig. 3. Transverse profiles of Maas river terraces in the Maastricht area, adapted from Westaway (2001), (Fig. 3), based on a diagram by Van den Berg (1996). Terrace alluvium is stippled. Italic letters indicate terraces with dating evidence: $M$, from magnetostratigraphy; $P$, from pollen; $\mathrm{R}$, from radiocarbon dating; and $\mathrm{S}$, from a soil profile. Age assignments to preferred oxygen isotope stages are indicated.
The Rhenish Massif also provides the possibility of testing the internal consistency of independent estimates of the effective viscosity $\eta_{\mathrm{e}}$ of the lower crust. First, using local heat flow data, Westaway (2001) estimated the typical temperature at the base of the plastic lower crust (at the top of the underlying layer of mafic underplating) as $\sim 640^{\circ} \mathrm{C}$. Using the calculation procedure from Westaway (1998), this temperature constrains $\eta_{\mathrm{e}}$ to between $\sim 10^{17} \mathrm{~Pa}$ s and $\sim 6 \times 10^{18}$ $\mathrm{Pa}$ s. Second, Westaway (2001) estimated from their geometry that the Middle and Late Pleistocene Scandinavian ice-sheets have been capable of sustaining time-averaged lateral pressure gradients, for driving lower crust southward to beneath the Rhenish Massif, of $\sim 15$ to $\sim 55 \mathrm{~Pa} \mathrm{~m}^{-1}$. From this range of pressure gradients and the spatial scale and estimated crustal thickening rate for the Rhenish Massif on this time scale, $\eta_{\mathrm{e}}$ was estimated by Westaway (2001) as $\sim 3 \times 10^{17} \mathrm{~Pa} s$ to $\sim 2 \times 10^{18} \mathrm{~Pa} \mathrm{~s}$. Finally, the large-scale mining of coal (lignite near Cologne and anthracite in the Ruhr region farther north) has unloaded the crust sufficiently to cause localised surface uplift at up to $\sim 2$ $\mathrm{mm} \mathrm{a}^{-1}$ (observed by repeated surveying over recent decades; Klein et al., 1997). Rheological modelling of this uplift by Klein et al. (1997) constrains $\eta_{\mathrm{e}}$ to between $\sim 3 \times 10^{17} \mathrm{~Pa} \mathrm{~s}$ and $\sim 10^{18} \mathrm{~Pa}$ s. These three inde- 


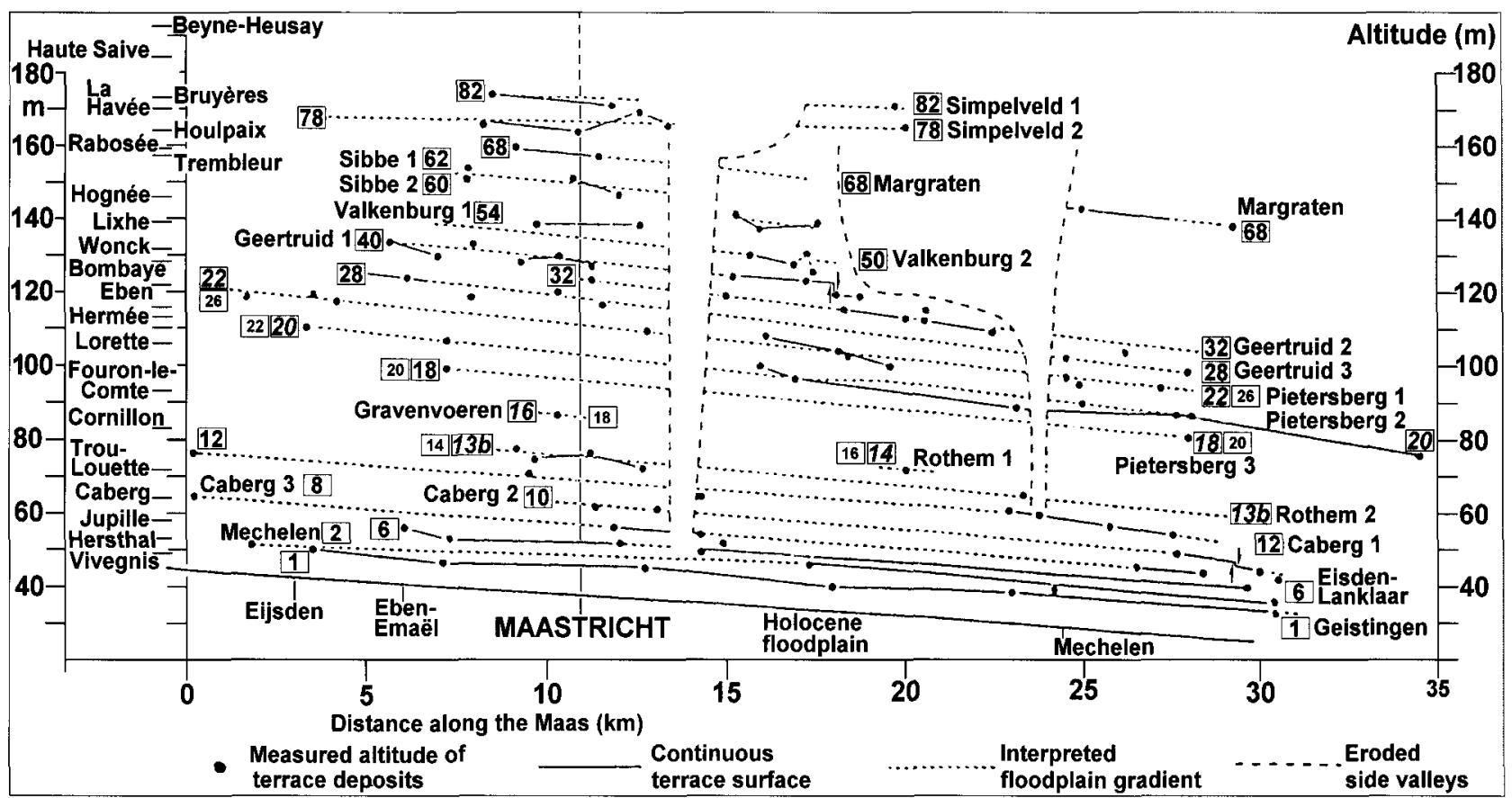

Fig. 4. Longitudinal profile of Maas river terraces in the Maastricht area, adapted from Westaway (2001), (Fig. 5c), based on a diagram from Van den Berg (1996). Terraces are labelled with the oxygen isotope stage numbers in which they formed, from Van den Berg (1996), except for the Middle Pleistocene, where Westaway's (2001) preferred ages are shown with Van den Berg's (1996) alternatives in smaller type. Note the offset of the Caberg 2 terrace across a strand of the Feldbiss normal fault zone north of Mechelen aan de Maas. Column to left of Fig. shows the terrace sequence documented by Juvigné \& Renard (1992) at St. Remy, upstream in northern Belgium.
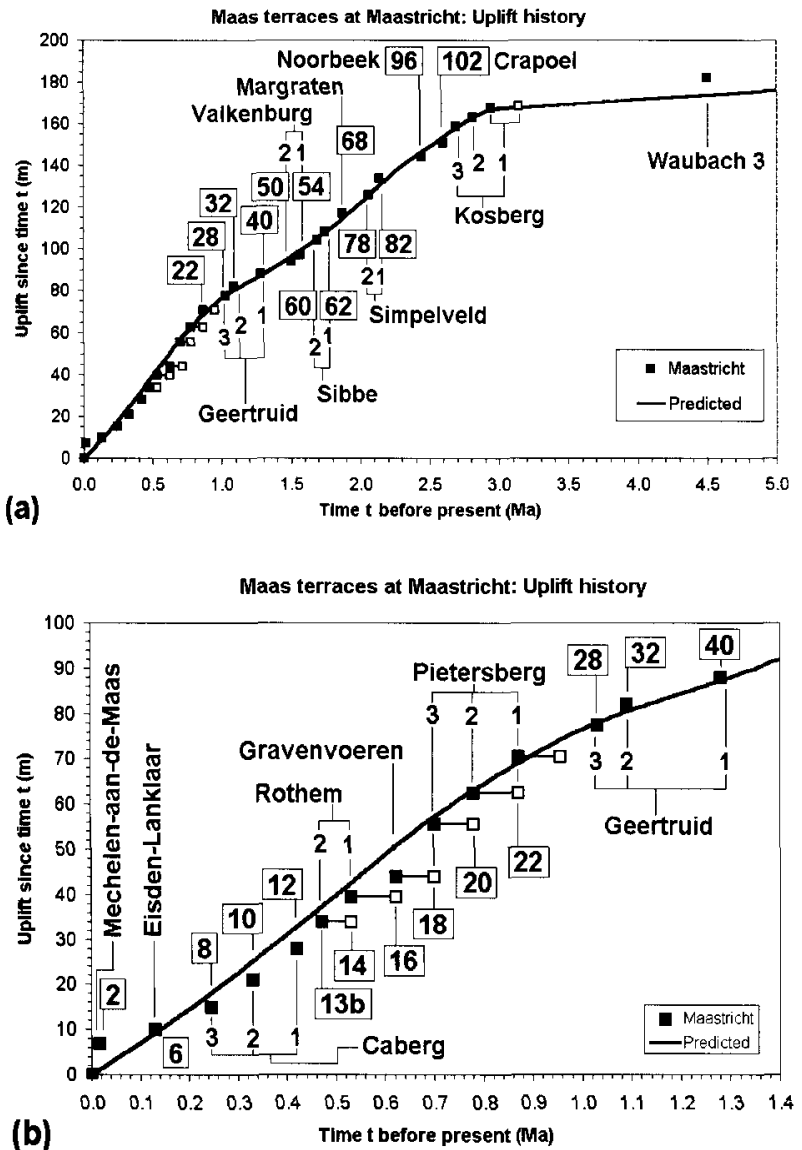

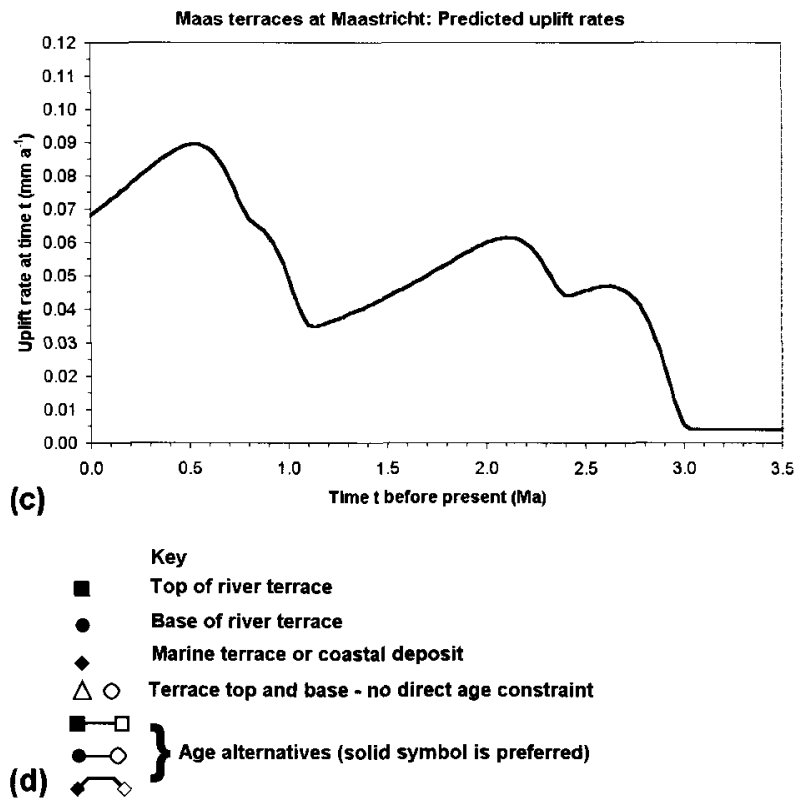

Fig. 5. (a) Observed and predicted uplift history at Maastricht. (b) Enlargement of (a), showing the Middle and Late Pleistocene in greater detail. (c) Predicted variation in uplift rate. (d) Key for this and later Fig.s. Predictions use u $20^{\circ} \mathrm{C} \mathrm{km}^{-1}, \mathrm{z}_{\mathrm{b}} 15.5 \mathrm{~km}, \mathrm{z}_{\mathrm{i}} 26 \mathrm{~km}$, $\Delta \mathrm{T}_{\mathrm{e} 1}-10.0^{\circ} \mathrm{C}, \Delta \mathrm{T}_{\mathrm{e} 2}-2.7^{\circ} \mathrm{C}, \Delta \mathrm{T}_{\mathrm{e} 3}-1.7^{\circ} \mathrm{C}, \Delta \mathrm{T}_{\mathrm{e} 4}-2.4^{\circ} \mathrm{C}$, and $\Delta \mathrm{T}_{\mathrm{e} 5}$ $-1.9^{\circ} \mathrm{C}$. Terrace chronology is from Van den Berg (1996), as modified by Westaway (2001). 


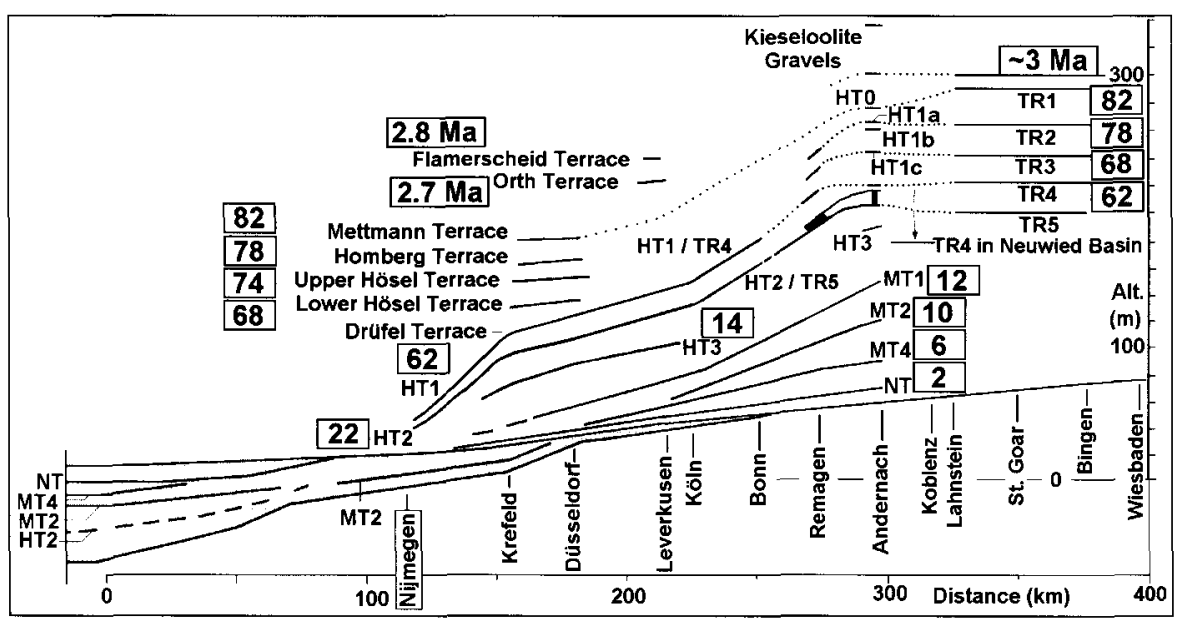

Fig. 6. Longitudinal profile of river terraces along the Middle and Lower Rhine, between the uplifting Rhenish Massif and the subsiding coastal region of the Netherlands. Adapted from Westaway (2001), (Fig. 10), showing information from Quitzow \& Thome (1975), Bibus \& Semmel (1977), Illies et al. (1979), Brunnacker et al. (1982a,b) and Semmel (1991).

pendent methods thus give consistent results for $\eta_{\mathrm{e}}$ in this region. The possible objection to the physical modelling summarised in Fig. 1, on the grounds that it requires implausibly low viscosities in the lower continental crust, is thus untenable.

\section{The Elbe, eastern Germany and the Czech Republic}

The Elbe has developed a long-term terrace profile across eastern Germany, but this is fragmentary due to course diversions caused by Scandinavian ice sheets (e.g., Präger, 1966; Lüttig \& Meyer, 1975) (Fig. 2). A clearer record exists upstream in the Czech
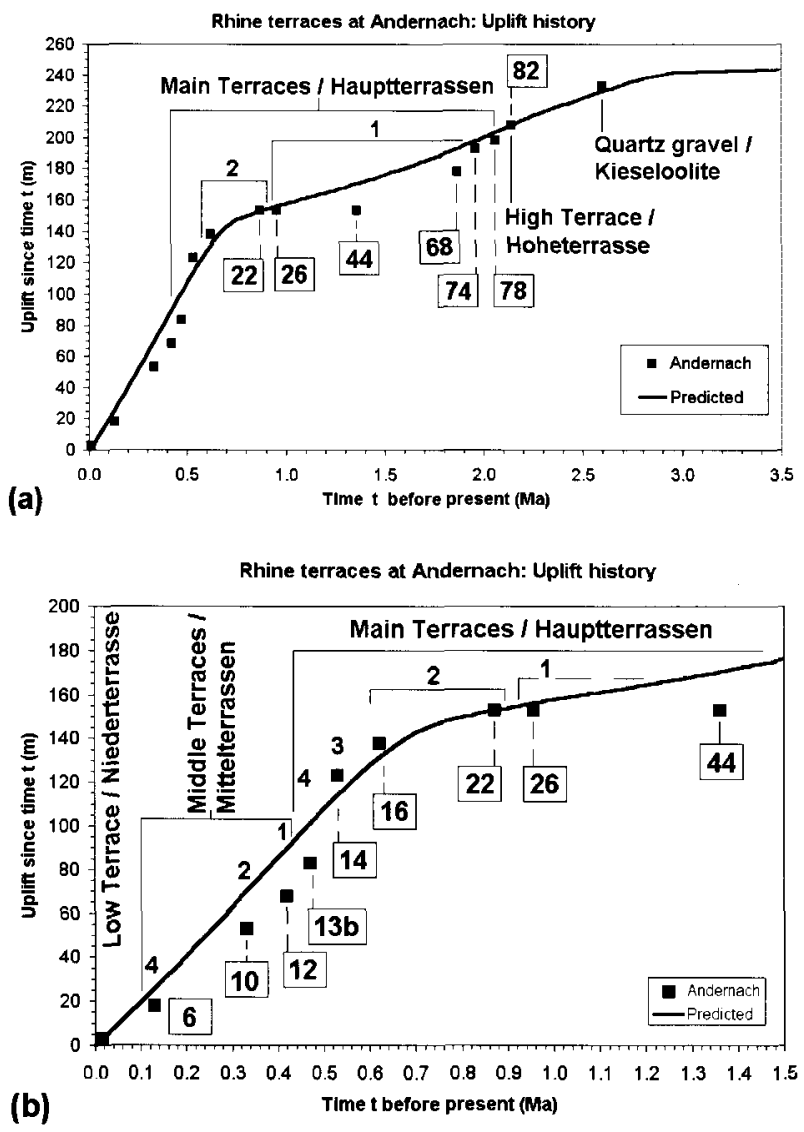

Republic, which has never been glaciated.

The best-documented terrace sequence, with 25 terraces, follows the Ohre tributary in the Most Basin (Tyracek, 1995) (Fig. 9 and 10). Within this basin, lignite seams have undergone spontaneous combustion when first exposed subaerially by gorge incision. As a result, they become magnetised with the contemporaneous field direction, facilitating magnetostratigraphic dating. The overall chronology is constrained by the recognition by Tyracek (1995) of the Gauss chron in the Dobrcice sediments, $\sim 140-165 \mathrm{~m}$ above river level; the Réunion subchron in clay covering the Vysocany (I-2) terrace; the Olduvai subchron

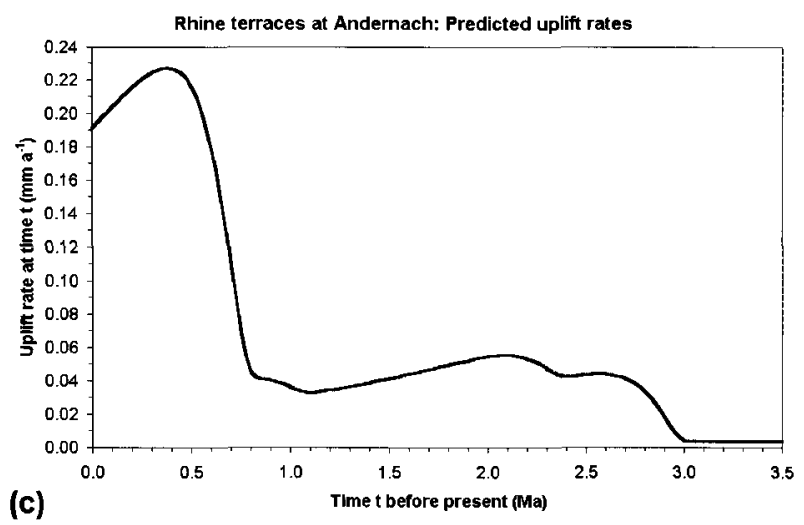

Fig. 7. (a) Observed and predicted uplift history at Andernach on the middle Rhine (Fig. 6). (b) Enlargement of (a), showing the Middle and Late Pleistocene in greater detail. (c) Predicted variation in uplift rate. Predictions use $\mathrm{u} 20^{\circ} \mathrm{C} \mathrm{km}^{-1}, \mathrm{z}_{\mathrm{b}} 15 \mathrm{~km}$, and $\mathrm{z}_{\mathrm{i}} 26$ $\mathrm{km}, \Delta \mathrm{T}_{\mathrm{e} 1}-9.0^{\circ} \mathrm{C}, \Delta \mathrm{T}_{\mathrm{e} 2}-2.8^{\circ} \mathrm{C}, \Delta \mathrm{T}_{\mathrm{e} 3}-1.5^{\circ} \mathrm{C}, \Delta \mathrm{T}_{\mathrm{e} 4}-1.0^{\circ} \mathrm{C}$, and $\Delta \mathrm{T}_{\mathrm{e} 5}-13.0^{\circ} \mathrm{C}$. Adapted from Westaway (2001), (Fig. 17), and based on the terrace chronology deduced in that study. 

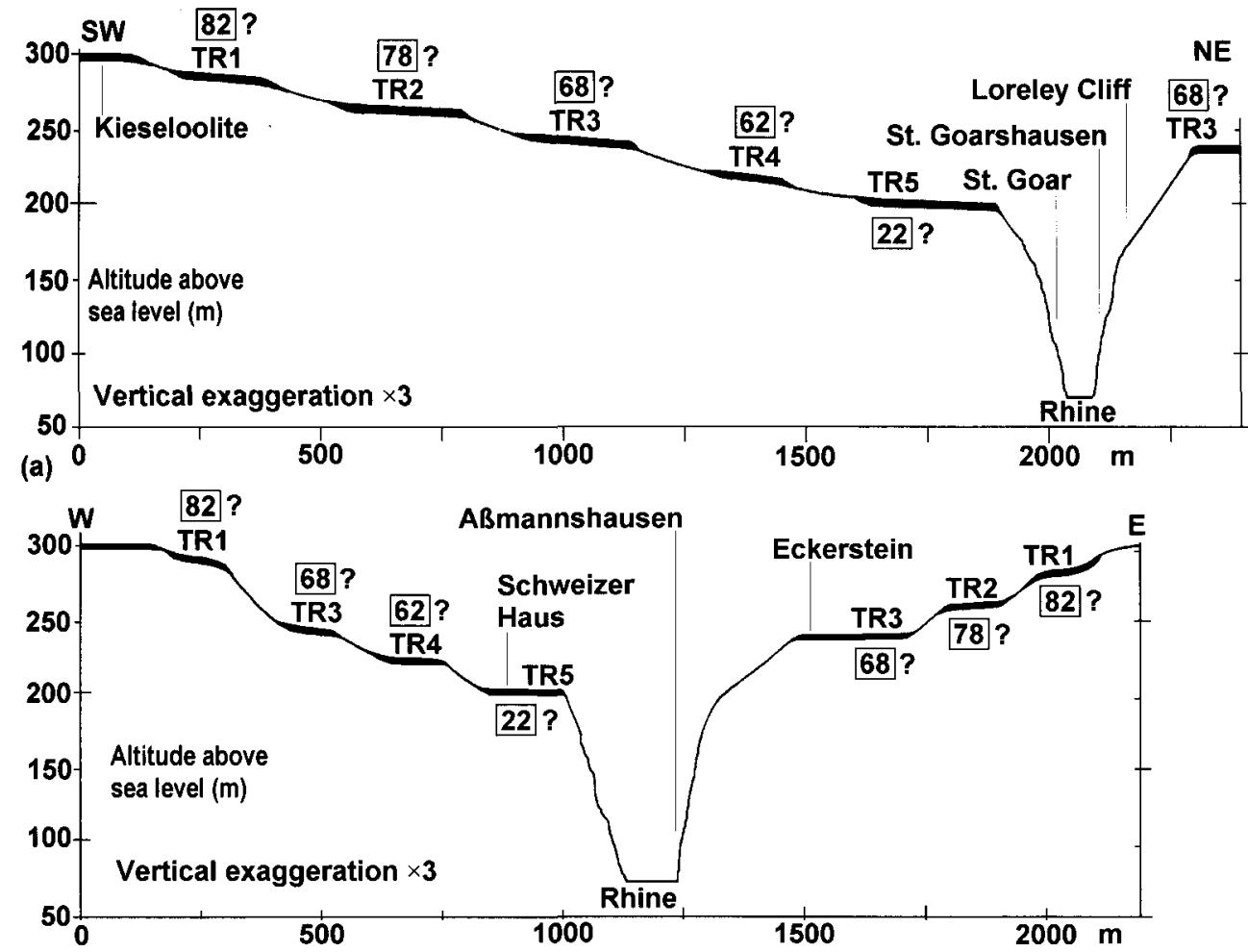

Fig. 8. Profiles of Middle Rhine terraces upstream of Koblenz, at St. Goar (a) and Aßmannshausen $(\sim 4 \mathrm{~km}$ north of Bingen; b), localities which are $22 \mathrm{~km}$ apart. Adapted from parts of Fig. 2 of Bibus \& Semmel (1977). Note the transition from a broad floodplain in the Early Pleistocene, when terraces TR1 to TR5 formed, to the present much narrower cliff-lined gorge around the end of depositon of terrace TR5. This is interpreted here as a consequence of faster incision caused by an increased rate of uplift of the adjacent land surface.

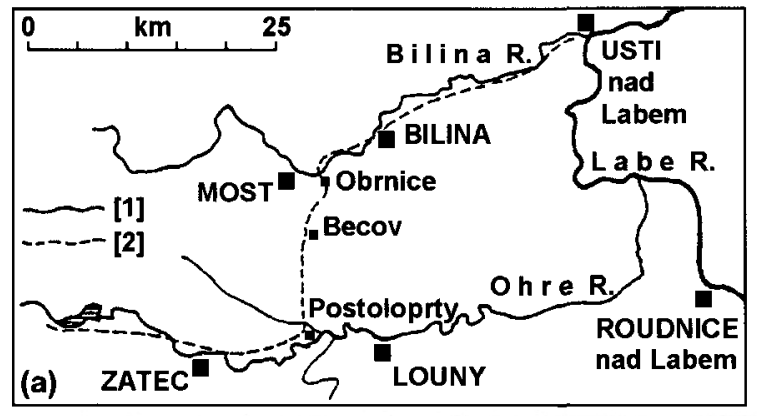

Fig. 9. Maps of the Ohre river in the Most Basin. (a) Summary map, showing the modern drainage pattern [1] and the shorter course of the Ohre until oxygen isotope stage 12. (b) More detailed map, showing the different river terrace groups and sites which have yielded age evidence. Adapted from Fig. 1 of Tyracek (1995).

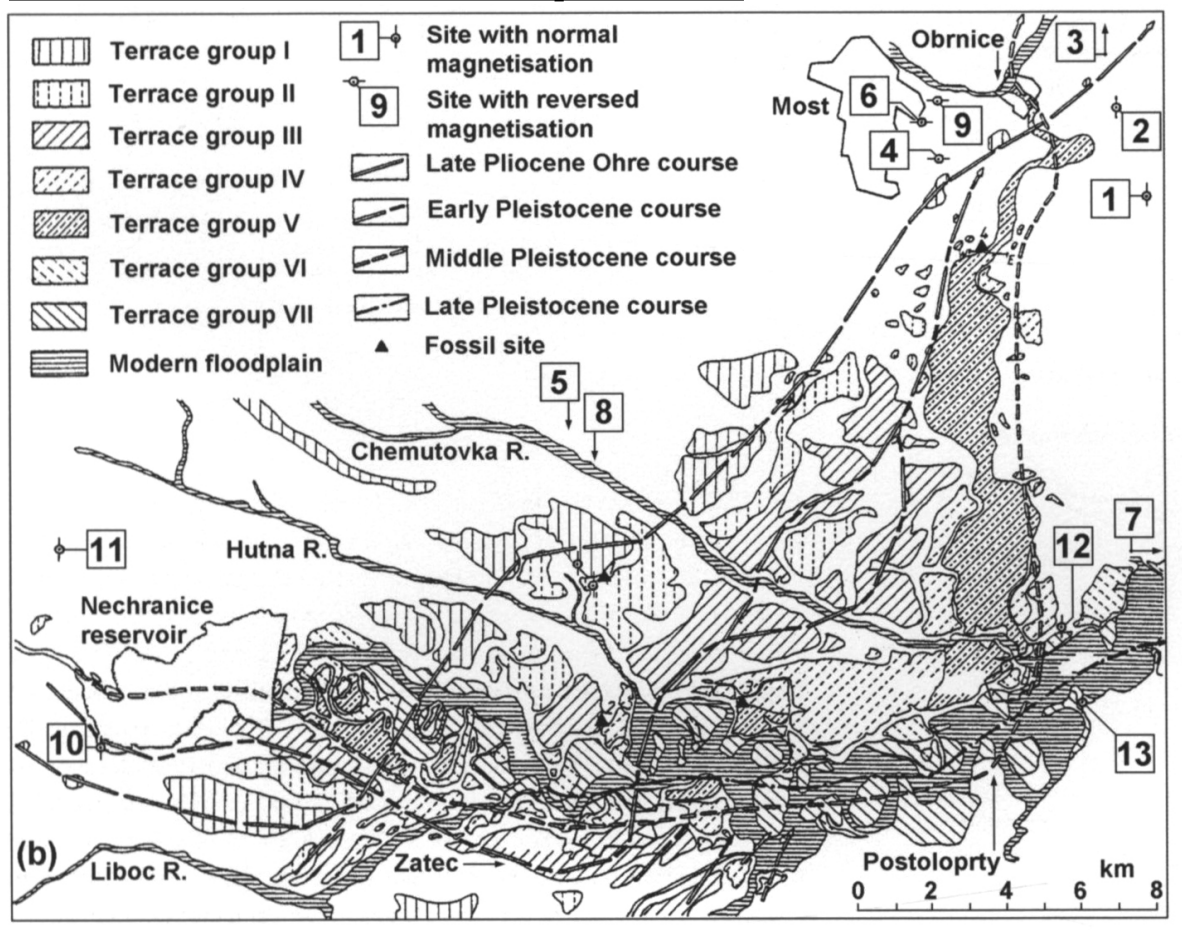




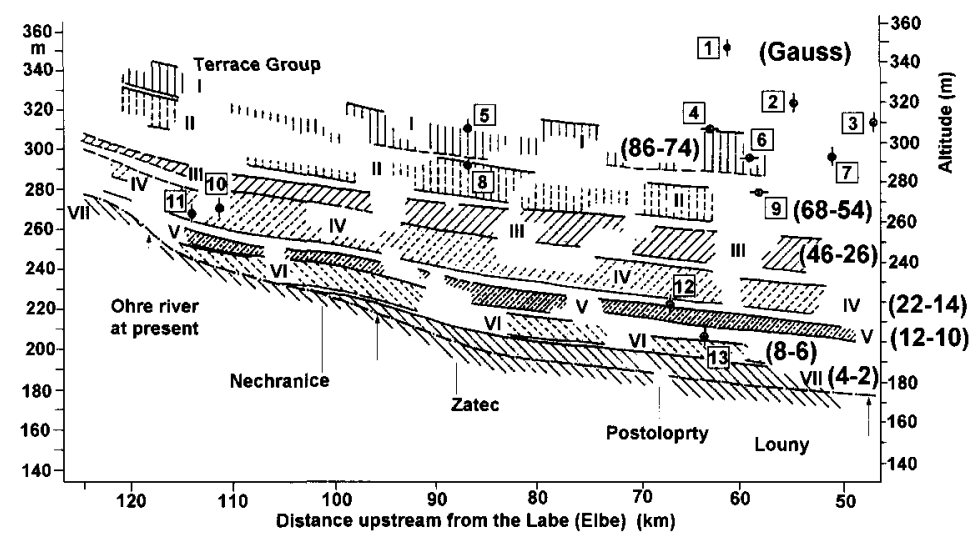

Fig. 10. Longitudinal profile of Ohre river terraces in the Most Basin, showing their assignments to terrace groups by Tyracek (1995) and interpreted oxygen isotope stages for aggradation. Adapted from Tyracek (1995), Fig. 7.

within the Hradec (II-1) terrace; and the Brunhes age of the Vyskov (IV-3) terrace (Fig. 10). Fig. 11 shows the resulting uplift history.

For comparison, only 10 terraces are identified along the Vltava tributary near Prague (Zaruba et al., 1977). Near the top of the oldest, the Zdiby terrace, $138 \mathrm{~m}$ above its latest Pleistocene counterpart, a sequence of polarity reversals probably marks the Réunion subchrons (Zaruba et al., 1977), indicating that aggradation ceased around oxygen isotope stage 74 (like Ohre terrace group 1; Fig. 10). Other evidence indicates that the Pankrac terrace, $75 \mathrm{~m}$ above its latest Pleistocene counterpart, is latest Matuyama (Zaruba et al., 1977), possibly indicating stage 22 .
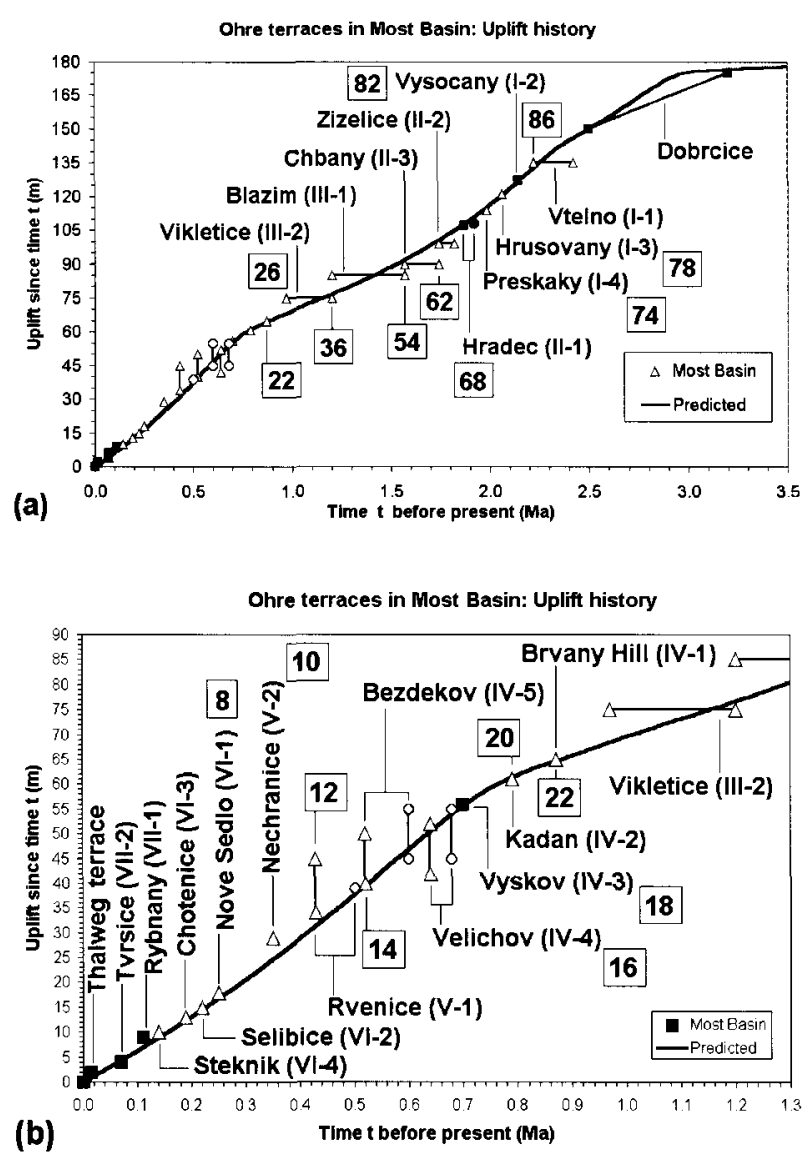

Slightly higher uplift rates are thus indicated than for the Most basin (Fig. 11), which has uplifted by 114 and $65 \mathrm{~m}$, respectively, on these time scales.

\section{The Thames, southern England}

Use of the Thames terrace record to deduce the uplift history of southeast England is complicated by channel length changes and the course diversion by the Anglian (oxygen isotope stage 12) ice sheet (Westaway et al., 2002) (Fig. 2). Fig. 13 shows the uplift history deduced at Reading, near the upstream limit of the middle Thames (Fig. 2), where Westaway et al. (2002) reported the greatest post-Middle Pliocene

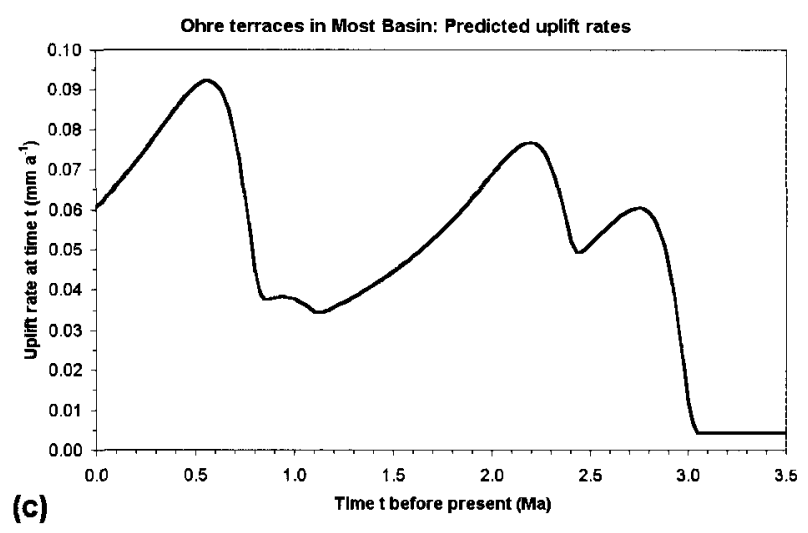

Fig. 11. (a) Observed and predicted uplift history at Postoloprty in the Most Basin (Fig. 9). (b) Enlargement of (a), showing the Middle and Late Pleistocene in greater detail. (c) Predicted variation in uplift rate. Predictions use $z_{b}=20 \mathrm{~km}, z_{\mathrm{i}}=29 \mathrm{~km}, \mathrm{u}=10^{\circ} \mathrm{C} \mathrm{km}^{-1}$, $\Delta \mathrm{T}_{\mathrm{e} 1}=-6.0^{\circ} \mathrm{C}, \Delta \mathrm{T}_{\mathrm{e} 2}=-1.3{ }^{\circ} \mathrm{C}, \Delta \mathrm{T}_{\mathrm{e} 3}=-0.9^{\circ} \mathrm{C}, \Delta \mathrm{T}_{\mathrm{e} 4}=-0.2^{\circ} \mathrm{C}$, and $\Delta \mathrm{T}_{\mathrm{e} 5}=-1.4^{\circ} \mathrm{C}$. Terrace names, age and altitude data, based on Tyracek (1995), are summarised in Fig. 10. A $10 \mathrm{~m}$ correction $(\sim 20$ $\mathrm{km}$ length change $\times 0.5 \mathrm{~m} \mathrm{~km}^{-1}$ river gradient) is added to convert incision to uplift for terraces up to the Rvenice (V-1) to correct for the channel shortening caused by the diversion of the Ohre river from its former course via Obrnice (Fig. 9), which is estimated here to have followed the Elster glaciation in oxygen isotope stage 12 . 


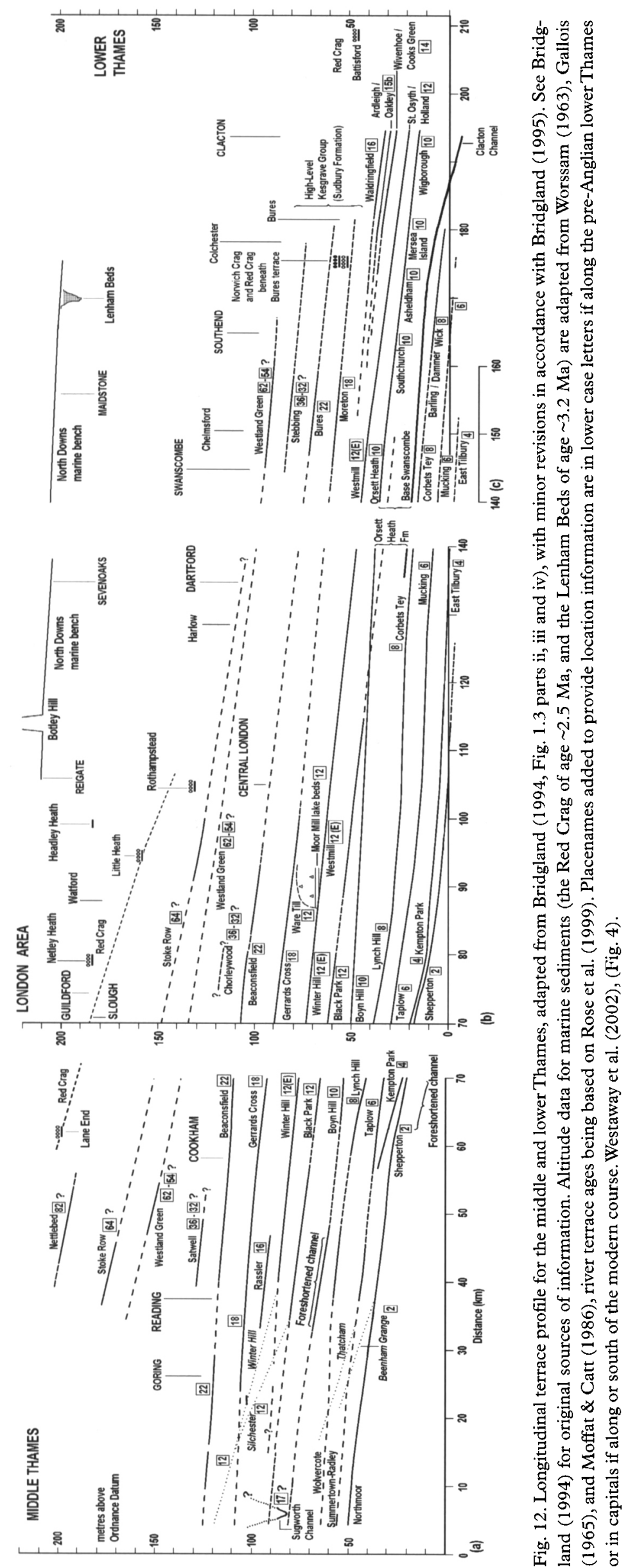


uplift. The Middle-Late Pleistocene uplift is roughly uniform, typically $\sim 60 \mathrm{~m}$, reflecting the parallelism of the youngest terraces (Fig. 12). In contrast, the earlier component decreases eastward, from $\sim 200 \mathrm{~m}$ of uplift at Reading to tens of metres of subsidence at the North Sea coast. The less detailed terrace record for the upper Thames supports a westward continuation of this trend, indicating $\sim 300 \mathrm{~m}$ of total uplift (Maddy et al., 2001).

The clearest mismatch evident in Fig. 13b is between the $34 \mathrm{~m}$ of uplift, estimated from the net incision since deposition of the Winter Hill terrace during
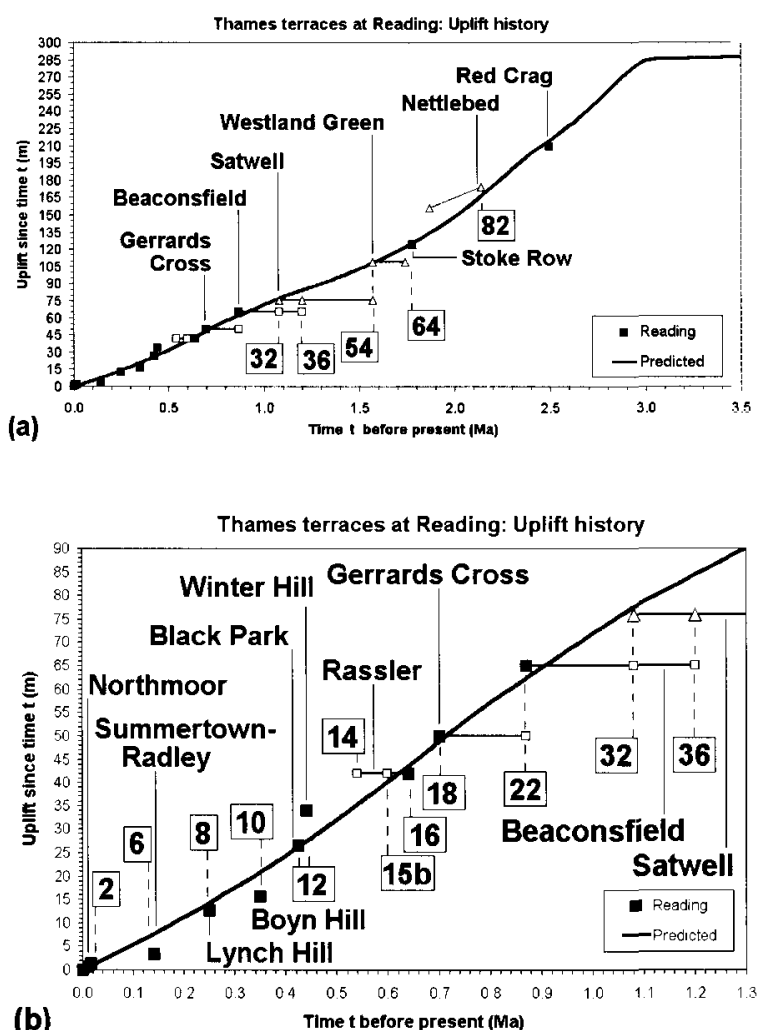

(b)

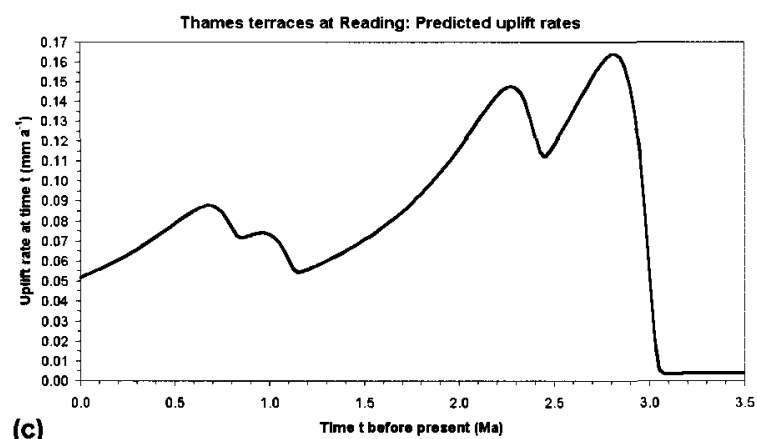

Fig. 13. (a) Observed and predicted uplift history at Reading on the middle Thames. (b) Enlargement of (a), showing the Middle and Late Pleistocene in greater detail. (c) Predicted variation in uplift rate. Predictions use $z_{b}=21 \mathrm{~km}, z_{i}=29 \mathrm{~km}, u=0.01^{\circ} \mathrm{C} \mathrm{m}^{-1}$, $\Delta \mathrm{T}_{\mathrm{el}}=-6.0^{\circ} \mathrm{C}, \Delta \mathrm{T}_{\mathrm{e} 2}=-2.9^{\circ} \mathrm{C}, \Delta \mathrm{T}_{\mathrm{e} 3}=-1.1^{\circ} \mathrm{C}, \Delta \mathrm{T}_{\mathrm{et}}=-0.5^{\circ} \mathrm{C}$, and $\Delta \mathrm{T}_{\mathrm{c} 5}=-0.5^{\circ} \mathrm{C}$. Terrace names, age and altitude data are from Fig. 12 , uplift being derived from incision after correction for channel length changes as described in detail by Westaway et al. (2002).
OIS 12 , and the model prediction of $27 \mathrm{~m}$ over the same time scale. In accordance with Maddy \& Bridgland (2000), this can be explained as a result of this gravel having been deposited while the adjacent crust was loaded by the Anglian ice sheet. After this ice melted, the crust rebounded, raising this terrace to a higher-than-expected level. This effect is greater in localities farther downstream, nearer the Anglian ice margin, where it increases from $7 \mathrm{~m}$ to $15 \mathrm{~m}$ or more (Maddy \& Bridgland, 2000; Westaway et al., 2002).

\section{The Somme, northern France}

The Somme terrace chronology during the MiddleLate Pleistocene is constrained by magnetostratigraphy, amino-acid dating, and other evidence (e.g., Bates, 1993; Antoine, 1994; Antoine et al., 1998) (Fig. 14). Fig. 15 shows the resulting uplift history.

\section{The Seine, northern France}

The Seine terrace sequence (Fig. 16) also includes marine sediments near the English Channel coastline (Fig. 17). However, the resulting chronology has been difficult to interpret, due to inconsistencies within the dating evidence. Amino acid dating (Bates, 1993), uranium-series dating of tufa (Lautridou et al., 1999), biostratigraphic dating of Late Pliocene marine sediments (Morzadec-Kerfourn, 1997), and other studies (Antoine et al., 1998) suggest the age assignments in Figs. 16 and 17 and the uplift history in Fig. 18.

\section{The Huanghe, northeast margin of Tibet}

The Huanghe or Yellow River flows eastward from northeast Tibet, through regions of northern China with thick Quaternary loess. Magnetostratigraphic dating of this loess allows the ages of underlying river terrace gravels to be constrained. Li et al. (1997a) investigated the terrace sequence of the Daxia $\mathrm{He}$ river near Linxia (Fig. 19), just upstream of its confluence with the Huanghe. The seven terraces have altitudes ranging up to $\sim 2400 \mathrm{~m}, \sim 500 \mathrm{~m}$ above the river level.

Most of Tibet either drains internally or has low relief, as rivers have not had time to achieve overall equilibrium with their reaches outside the plateau (e.g., Shackleton \& Chang, 1988; Fielding et al., 1994). Nick points are thus evident along river gorges leaving the plateau, at altitudes of $\sim 3-4 \mathrm{~km}$ (Shackleton \& Chang, 1988). The parts of their courses at lower altitudes may thus achieve equivalent states of quasi-equilibrium during each climate cycle.

The oldest terrace, $\mathrm{T} 7$, formed at $\sim 1.7 \mathrm{Ma}$ ( $\mathrm{Li}$ et 


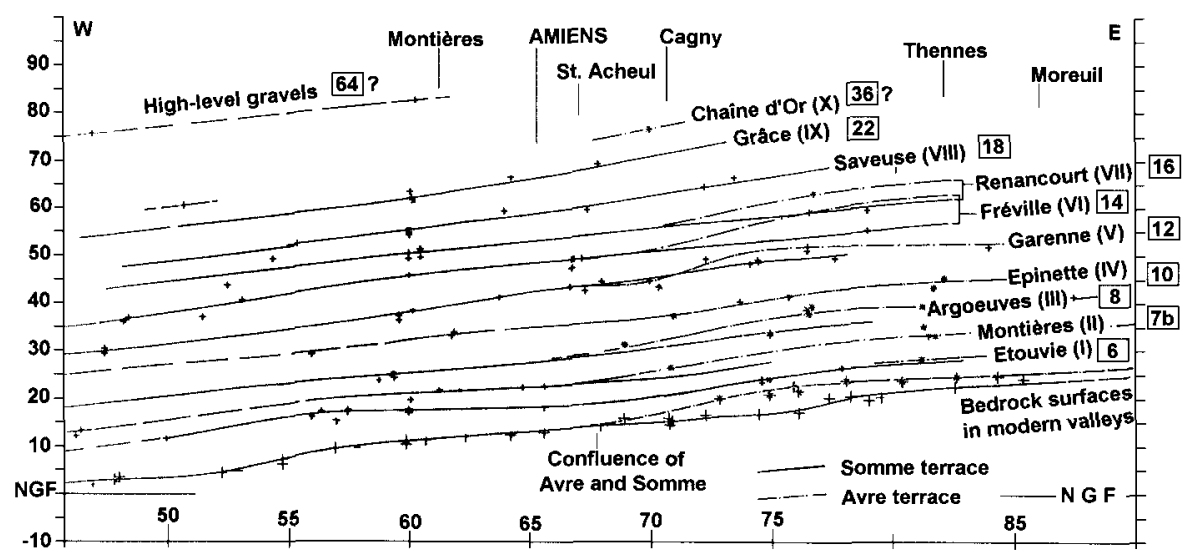

Fig. 14. Longitudinal profile of Somme river terraces around Amiens, adapted from Antoine (1994), (Fig. 2).
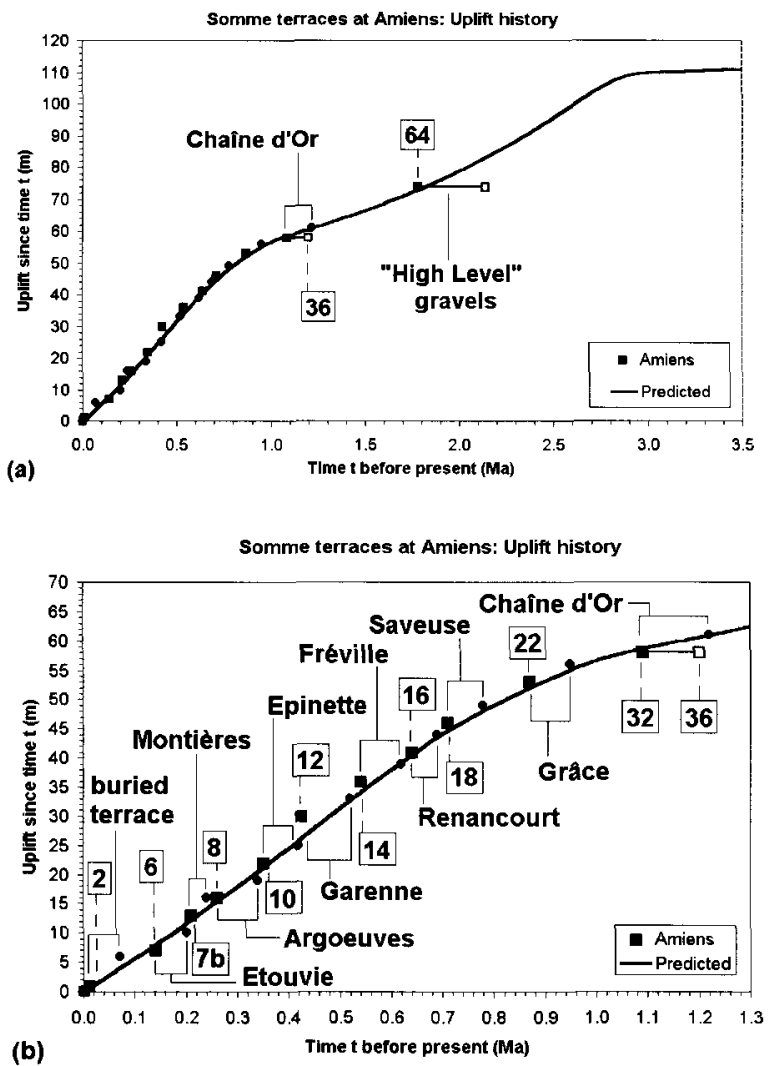

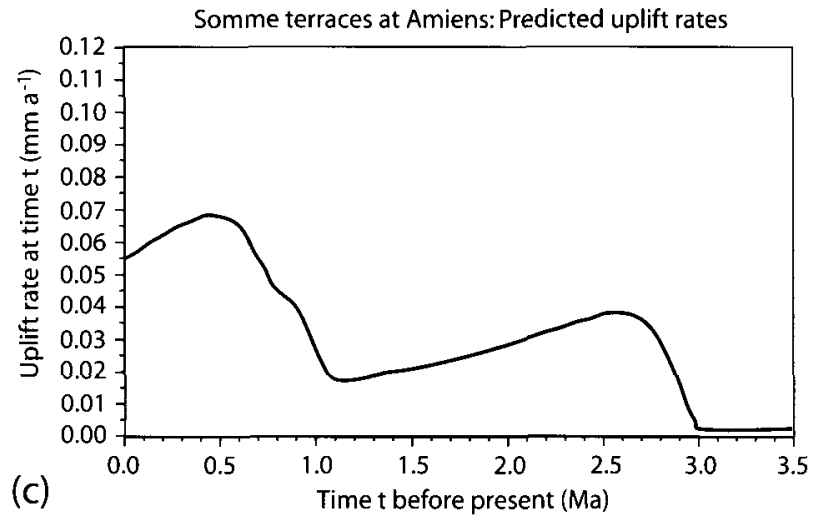

Fig. 15. (a) Observed and predicted uplift history at Amiens. (b) Enlargement of (a), showing the Middle and Late Pleistocene in greater detail. (c) Predicted variation in uplift rate. Predictions use $\mathrm{z}_{\mathrm{b}}=16 \mathrm{~km}, \mathrm{z}_{\mathrm{i}}=27 \mathrm{~km}, \mathrm{u}=20^{\circ} \mathrm{C} \mathrm{km}-1, \Delta \mathrm{T}_{\mathrm{e} 1}=-6.0^{\circ} \mathrm{C}, \Delta \mathrm{T}_{\mathrm{e} 2}=-2.5^{\circ} \mathrm{C}$, $\Delta \mathrm{T}_{\mathrm{e} 3}=0^{\circ} \mathrm{C}, \Delta \mathrm{T}_{\mathrm{e} 4}=-2.2^{\circ} \mathrm{C}$, and $\Delta \mathrm{T}_{\mathrm{e} 5}=-1.8^{\circ} \mathrm{C}$. Terrace names, age and altitude data are from Fig. 14, based on Antoine (1994).

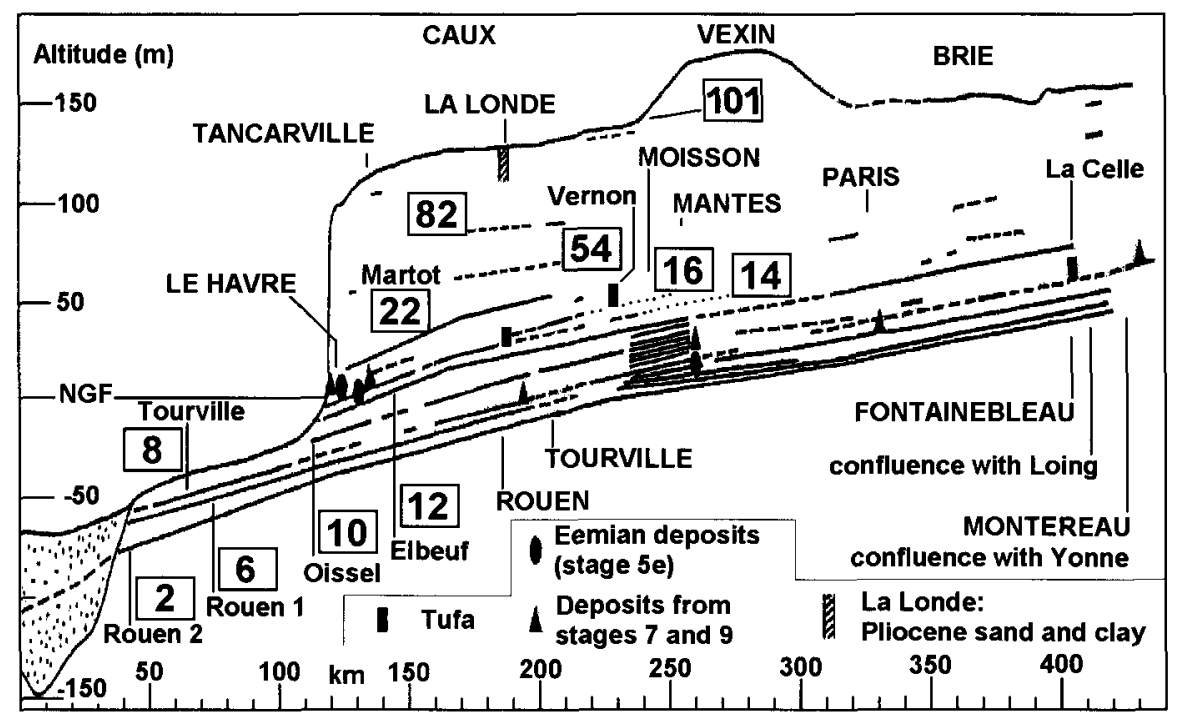

Fig. 16. Longitudinal profile of Seine river terraces, adapted from Lautridou et al. (1999), Fig. 3. 


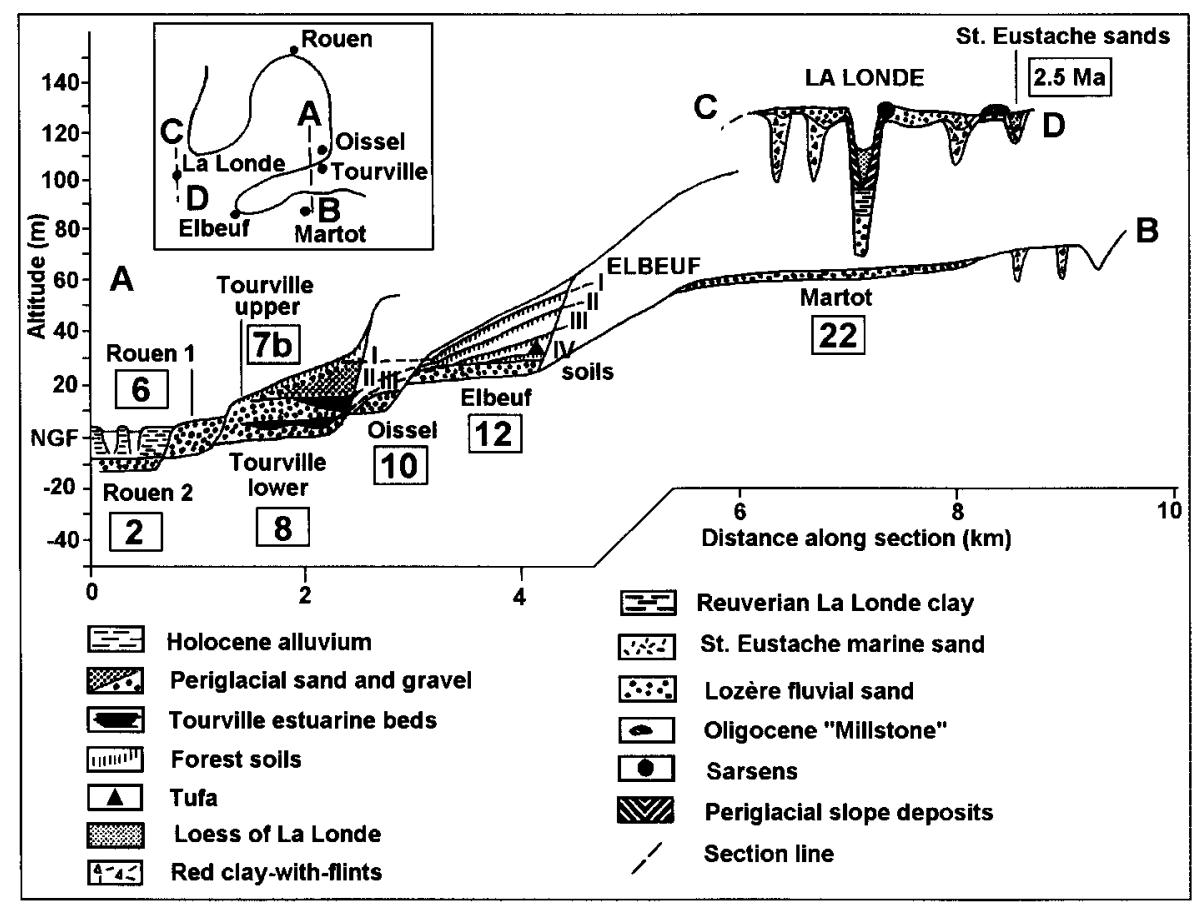

Fig. 17. Transverse profile of Seine river terraces around Rouen, adapted from Lautridou et al. (1999), (Fig. 2).

al., 1997a), on slightly older lake sediment (Fig. 19) (Li et al., 1997b), thus indicating the first appearance of the throughgoing Huanghe river system. Earlier, this region evidently drained internally (e.g., Li et al., 1997a), presumably resembling the modern Tibetan plateau interior. The interval between terraces $\mathrm{T} 7$ and T6 thus does not represent the transition between
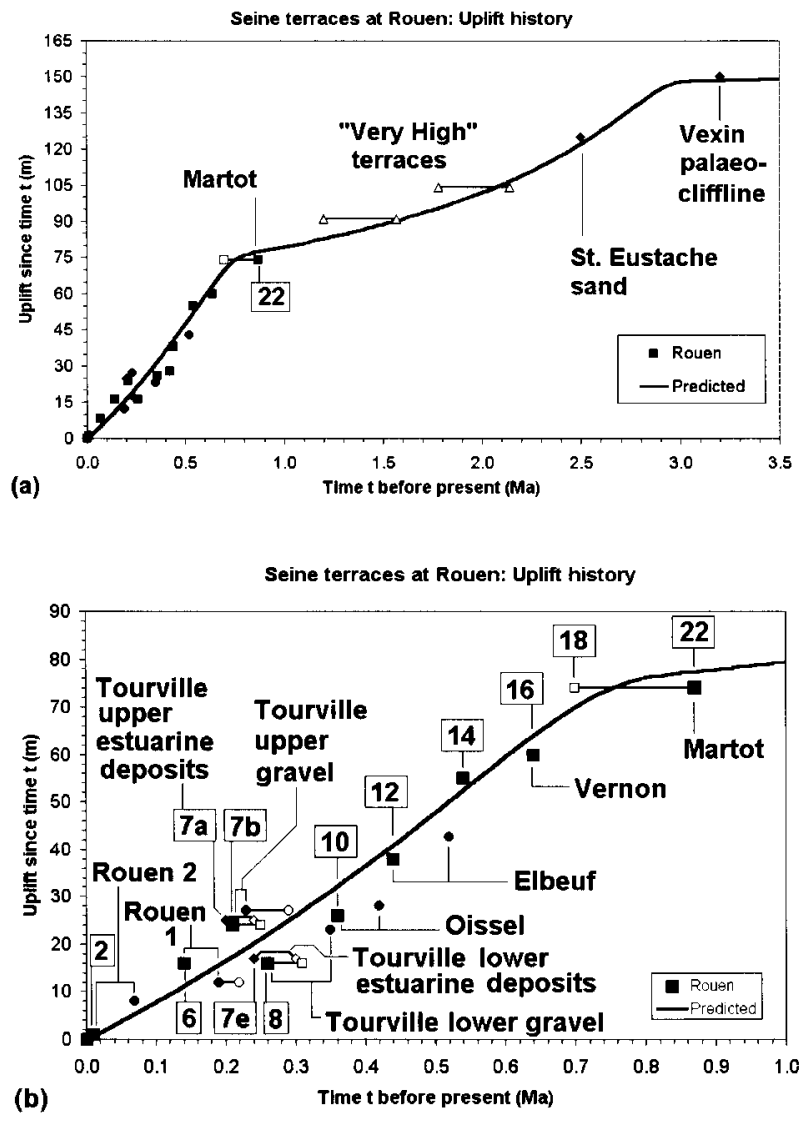

equivalent states: it represents initial incision of an incipient river gorge, and thus does not imply $\sim 250 \mathrm{~m}$ of uplift in $\sim 0.25 \mathrm{Ma}$. However, the increase in incision rates in the Late Pleistocene (Fig. 20) is not a local effect, being widely observed elsewhere around the margins of Tibet (e.g., Li, 1991; Li et al., 1997a)

Unlike the localities already studied, where rivers

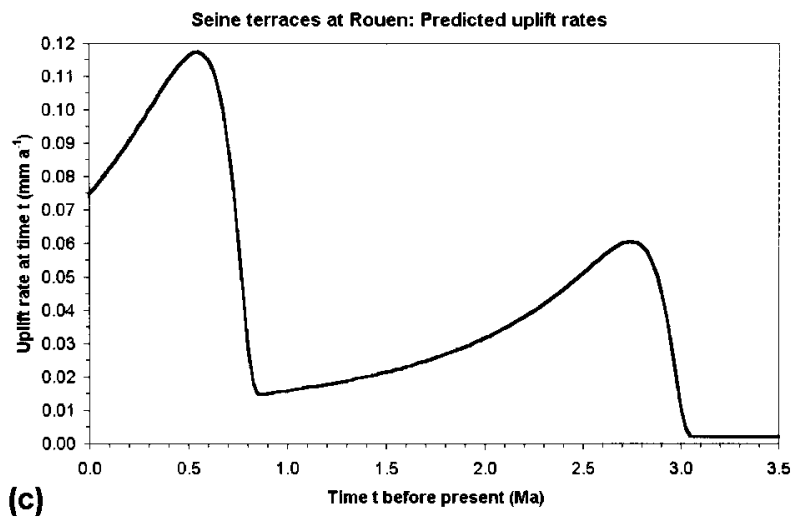

Fig. 18. (a) Observed and predicted uplift history at Rouen. (b) Enlargement of (a), showing the Middle and Late Pleistocene in greater detail. (c) Predicted variation in uplift rate. Predictions use $\mathrm{z}_{\mathrm{b}}=20 \mathrm{~km}, \mathrm{z}_{\mathrm{i}}=29 \mathrm{~km}, \mathrm{u}=20^{\circ} \mathrm{C} \mathrm{km}^{-1}, \Delta \mathrm{T}_{\mathrm{e} 1}=-6.0^{\circ} \mathrm{C}, \Delta \mathrm{T}_{\mathrm{e} 2}=-2.7^{\circ} \mathrm{C}$, $\Delta \mathrm{T}_{\mathrm{e} 3}=0^{\circ} \mathrm{C}, \Delta \mathrm{T}_{\mathrm{e} 4}=0^{\circ} \mathrm{C}$, and $\Delta \mathrm{T}_{\mathrm{e} 5}=-4.8^{\circ} \mathrm{C}$. Terrace names, age and altitude data are from Figs 16 and 17, based on Lautridou et al. (1999). 


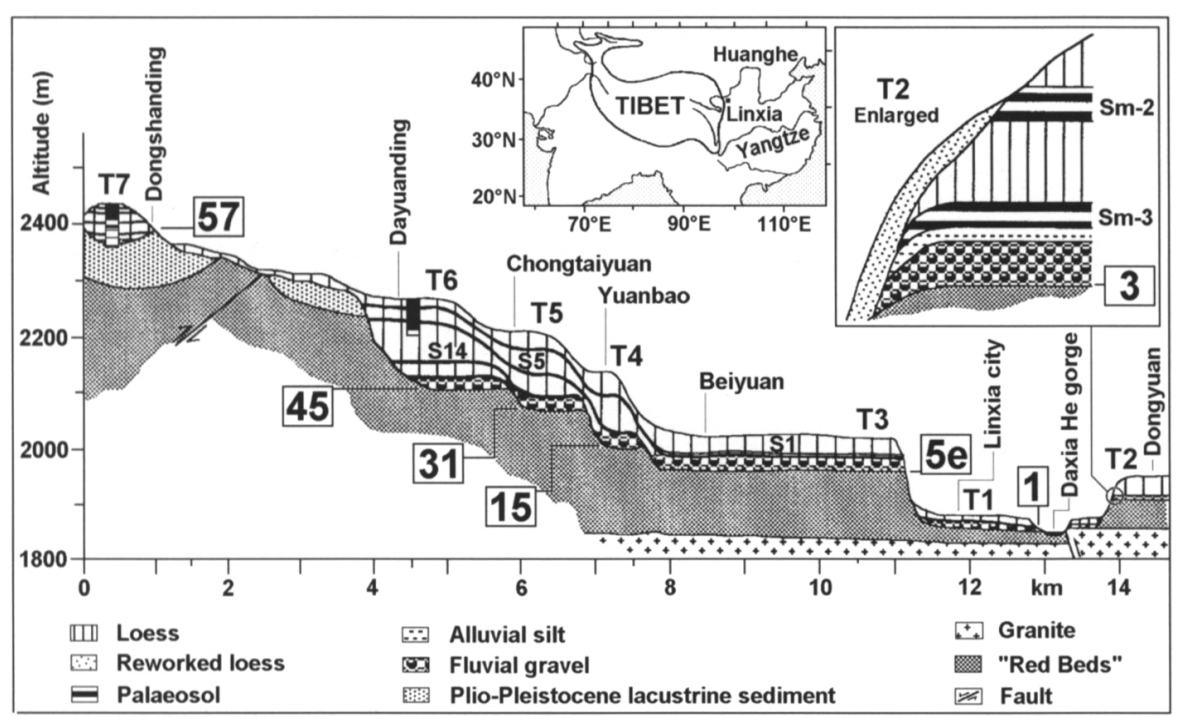

Fig. 19. Transverse profile through the terrace sequence of the Daxia $\mathrm{He}$ river near Linxia, northern China, just upstream of its confluence with the Huanghe, adapted from $\mathrm{Li}$ et al. (1997a), Fig. 2. Loess beds are labelled for comparison with $\mathrm{Li}$ et al.'s (1997a) magnetostratigraphic studies, which lead to the indicated oxygen isotope stages for formation of the land surfaces on which the basal gravels of each terrace were deposited.

are near sea level in crust of normal $\sim 30 \mathrm{~km}$ thickness, the crust around Linxia is $\sim 50 \mathrm{~km}$ thick (e.g., Ma et al., 1982), roughly as is expected when in isostatic equilibrium with the Earth's surface at $\sim 2.0-2.5 \mathrm{~km}$ altitude. These isostatic calculations assume that the crustal thickening has been unaccompanied by thickening of the mantle lithosphere, as is expected if the crust has thickened by inward lower-crustal flow that leaves the mantle lithosphere unaffected (see, e.g., Westaway, 1995). This crustal thickening is transi-
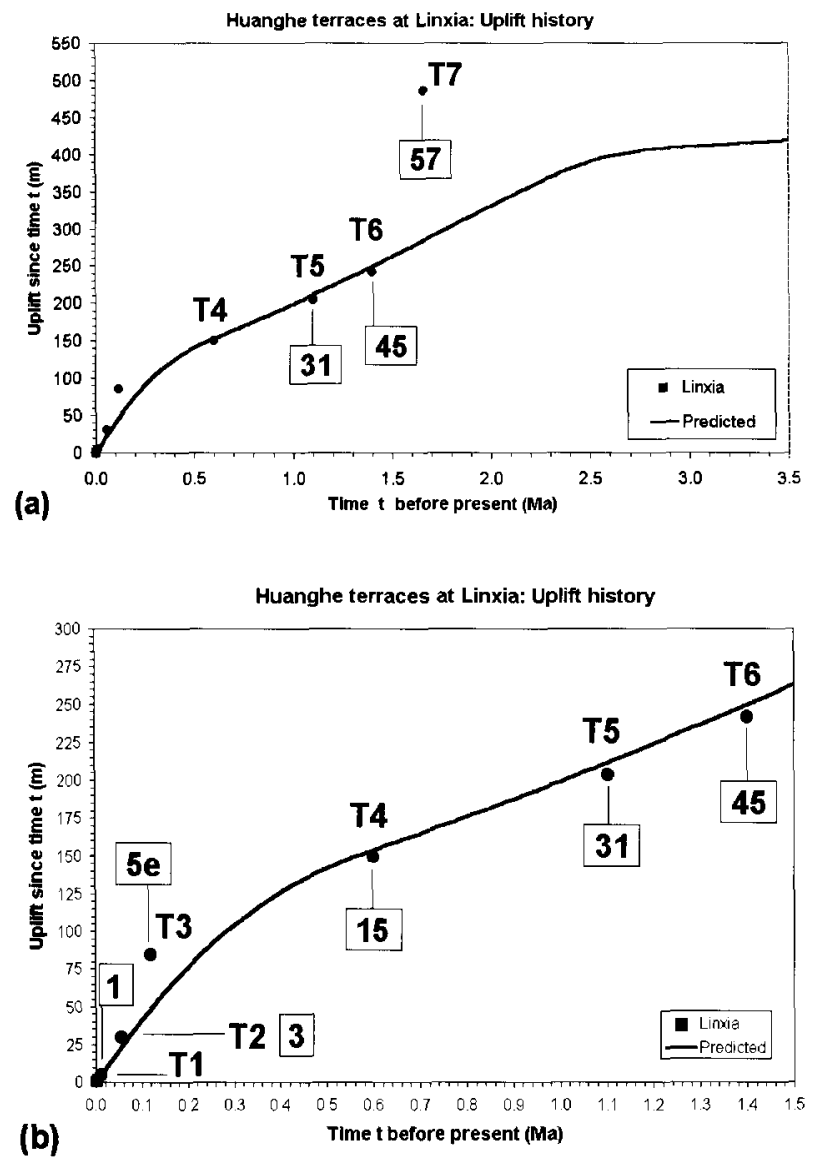

tional to the Tibetan plateau interior, where the crust is $\sim 65 \mathrm{~km}$ thick with a surface altitude of $\sim 5 \mathrm{~km}$ (e.g., Fielding et al., 1994).

Fig. 20 shows a solution from modelling the Linxia terraces. It implies that the increase in incision rate in the Late Pleistocene results from an increase in the uplift rate, analogous to the increase in the early Middle Pleistocene in other localities. The response at Linxia to the intensified forcing starting at $0.9 \mathrm{Ma}$ is delayed because of the greater thickness of lower crust.

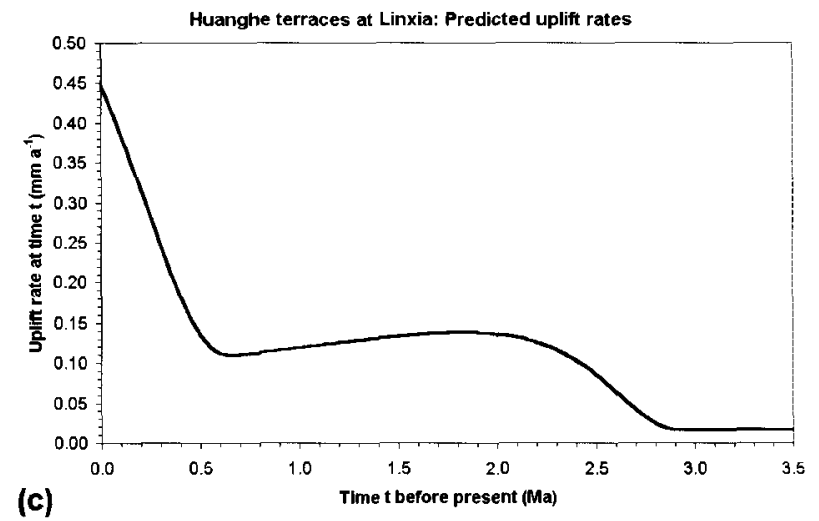

Fig. 20. (a) Observed and predicted uplift history at Linxia. (b) Enlargement of (a), showing the Middle and Late Pleistocene in greater detail. (c) Predicted variation in uplift rate. Predictions use $\mathrm{z}_{\mathrm{b}}=20 \mathrm{~km}, \mathrm{u}=10^{\circ} \mathrm{C} \mathrm{km} \mathrm{km}^{-1}, \Delta \mathrm{T}_{\mathrm{el}}=-15^{\circ} \mathrm{C}, \Delta \mathrm{T}_{\mathrm{e} 2}=-10^{\circ} \mathrm{C}, \Delta \mathrm{T}_{\mathrm{e} 3}=0^{\circ} \mathrm{C}$, $\Delta \mathrm{T}_{\mathrm{e} 4}=0^{\circ} \mathrm{C}$, and $\Delta \mathrm{T}_{\mathrm{e} 5}=-60^{\circ} \mathrm{C}$, with $\mathrm{z}_{\mathrm{i} 1}=35 \mathrm{~km}, \mathrm{z}_{\mathrm{i} 2}=37 \mathrm{~km}$, and $\mathrm{z}_{\mathrm{i}}=40$ $\mathrm{km}$ thereafter. Terrace numbers and altitude data are from $\mathrm{Li}$ et al. (1997a). 
It is of interest to compare marine terrace records with the data already described. Clear long-term marine terrace sequences occur on islands in the outer California Continental Borderland, the $\sim 200 \mathrm{~km}$ wide region of submerged continental crust offshore of southern California (Fig. 21) (e.g., Legg, 1991). This Borderland structure formed by right-lateral strikeslip faulting at the boundary between the Pacific and North American plates, which ended at $\sim 5 \mathrm{Ma}$ when this plate boundary adjusted eastward to its present inland position (e.g., Atwater, 1987; Legg, 1991). The complex seafloor relief (Fig. 21) is inherited from this time: the bathymetric deeps mark pull-apart basins where strike-slip faults stepped to the right. At present, the component of plate motion taken up across this Borderland is negligible (e.g., Larson, 1993). The nearshore basins trap sediment transported to the coast by rivers, and thus experience rapid sedimentation (e.g., Gorsline \& Teng, 1989). The outer basins are thus sediment-starved (e.g., Schwalbach \& Gorsline, 1985), which preserves the inherited relief. The marine terraces on San Clemente island were described by Lawson (1893) and Smith $(1898,1900)$
(Fig. 22). Lawson (1893) reported 22 terraces up to $\sim 460 \mathrm{~m}$ altitude, with the higher land up to the $599 \mathrm{~m}$ summit not terraced. Smith's (1898) sequence agrees closely with Lawson (1893). For decades since, most of San Clemente has been inaccessible for fieldwork due to its use as a target range by the U.S. Navy; fieldwork having only been possible on the northern half of the west coast (e.g., Muhs \& Szabo, 1982; Muhs, 1983; Muhs et al., 1994). Here, the limited altitude range restricts which terraces can be studied, but most have been dated using uranium series or amino acid methods. Ages of the older terraces are tentatively estimated here by matching them to major interglacials, from Shackleton et al. (1990) and Hilgen (1991), assuming by analogy with the sequences already described that the oldest dates from $\sim 3.1 \mathrm{Ma}$ and the uplift rate beforehand was minimal. Fig. 23 shows the resulting uplift history.

Rising to $276 \mathrm{~m}$, San Nicolas (Fig. 21) has $14 \mathrm{ma}-$ rine terraces (Vedder \& Norris, 1963; Muhs, 1985). Terrace 14 occupies the highest land, with no shoreline angle, indicating that only a shoal existed when it formed. Several terraces are dated using the uranium series and amino acid methods (e.g., Valentine \& Veeh, 1969; Wehmiller et al., 1977; Muhs, 1985;

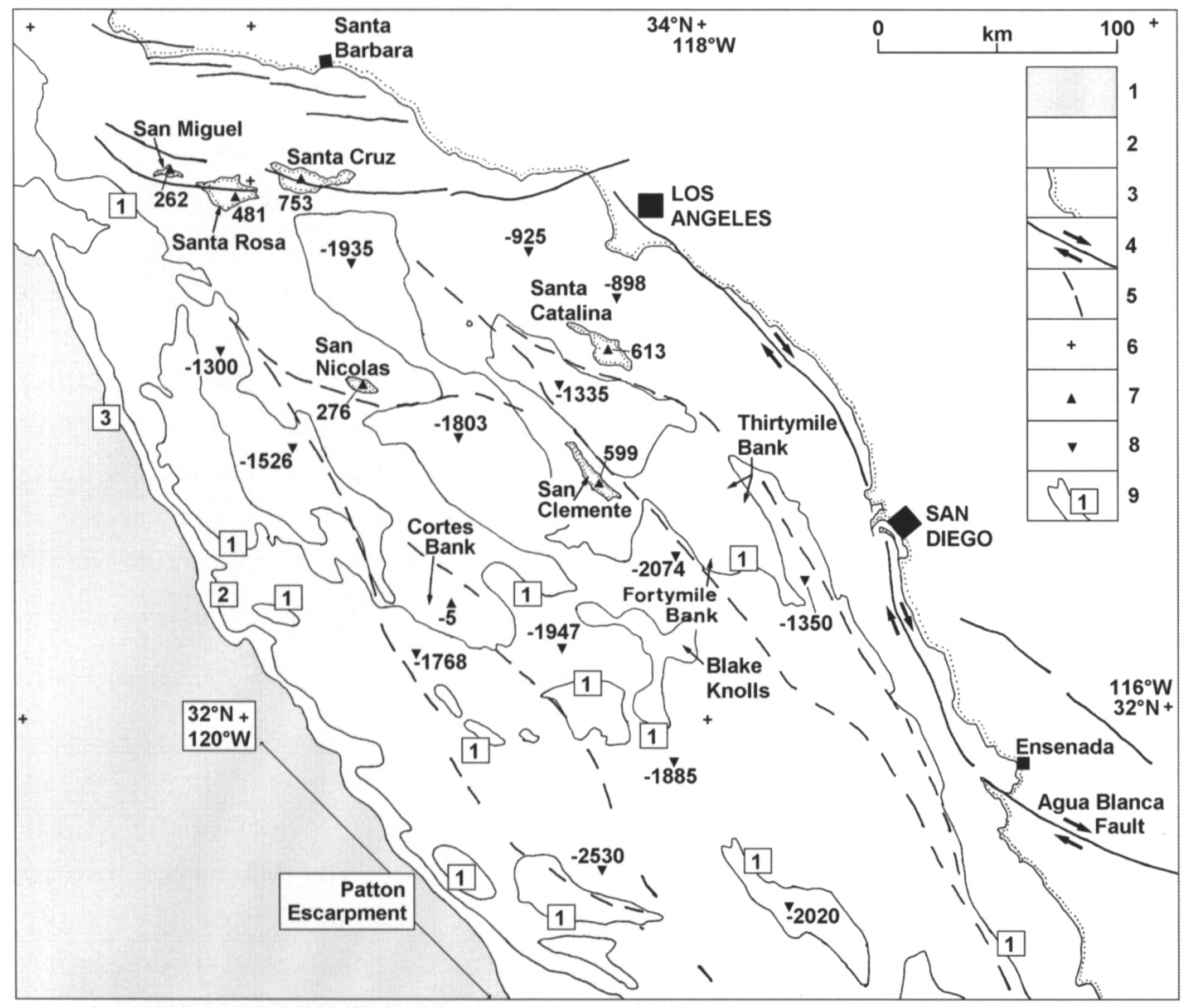

Fig. 21. Map of the California Continental Borderland showing the locations of San Nicolas and San Clemente islands and the surrounding deep water basins. Key denotes: 1, oceanic crust of the Pacific abyssal plain; 2, continental crust; 3, coastline, with ornament on the landward side; 4, faults active with significant Pliocene and Quaternary slip rates, with paired arrows indicating sense of strike-slip; 5, faults which were active in the Miocene, before the modern Pacific-North American plate boundary developed, some of which may remain active with low slip rates; 6 , selected intersections of parallels and meridians at $1^{\circ}$ intervals; 7 , spot heights and depths of shoals in metres; 8 , depths of deepest water, in metres; 9 , bathymetric contours, in kilometres. 


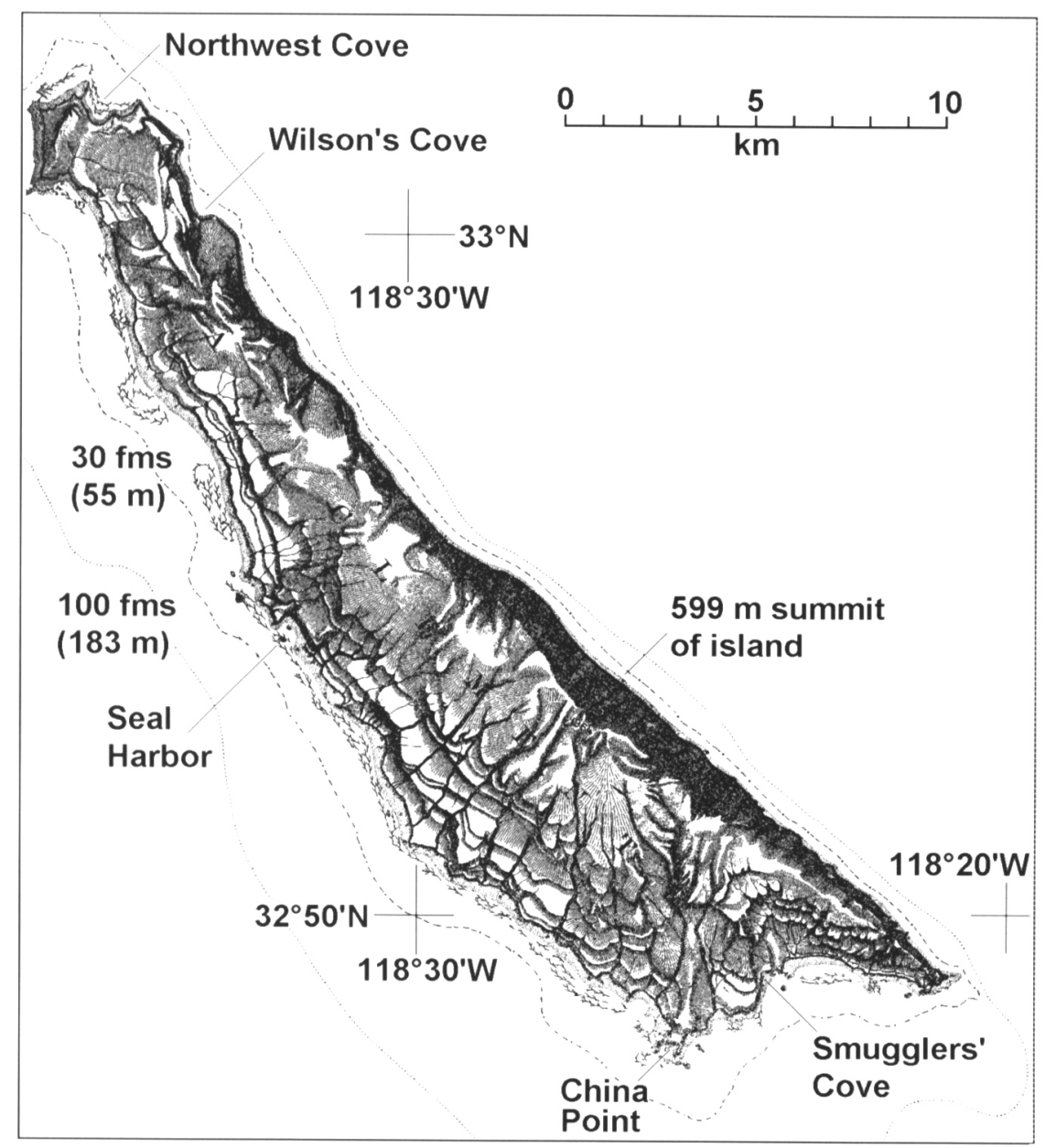

Fig. 22. Relief-shaded topographic map of San Clemente, adapted from Lawson (1893) (Plate 8 , facing page 138). The original Fig. was based on a contemporaneous 1:200,000 scale map published by the U.S. Coast and Geodetic Survey.

Muhs et al., 1994). The others are tentatively assigned here to major interglacials, as for San Clemente (Fig. 24).

The modelling in Figs. 23 and 24 suggests that the same atectonic uplift process can account for the marine terraces on these small islands and the river terraces described earlier. However, Ward \& Valensise (1996) modelled the development of San Clemente as a result of uplift in the hanging-wall of a southwestdipping reverse fault. Such a fault would have no geometrical relationship with the San Clemente fault (e.g., Legg, 1991), a strike-slip fault inherited from the Miocene, which delineates the northeast coastline (Fig. 21). Ward \& Valensise (1996) deduced that this reverse fault accommodates NE-SW shortening between the Pacific and North American plates. Difficulties with this interpretation include, first, that no component of shortening in this direction is expected either from the overall sense of plate motion or from geodetic surveys (e.g., Larson, 1993). Second, no field evidence of active reverse faulting or seismological evidence of reverse-faulting microearthquakes has been reported. Finally, a seismic reflection profile which imaged the crust to $\sim 7 \mathrm{~km}$ depth, published by Ward \& Valensise (1996), showed no evidence for an active reverse fault. Subsequent improved seismic imaging by ten Brink et al. (2000) likewise did not reveal any such reverse fault. Ward \& Valensise (1996) also claimed that slip on another active reverse fault may cause the uplift of San Nicolas, although there is no evidence for an active reverse fault there, either. The similarity in uplift histories of both islands anyway appears better explained as a consequence of the same global forcing mechanism, as I suggest, rather than requiring both hypothetical reverse faults to slip at the same rate.

\section{Other localities}

Many other localities also provide evidence for an increase in uplift rates around the start of the Middle Pleistocene. Examples include the Allier river terraces near Vichy in the French Massif Central (Veldkamp, 1992), and marine terrace sequences in diverse localities including southern Italy (e.g., Westaway, 1993b), southern Australia (e.g., Murray-Wallace et al., 1996), and the Indonesian island of Sumba (e.g., Pirazzoli et al., 1991). Some people, including myself (Westaway, 1993b), have tried to explain such increases in uplift rates as a consequence of changes in 

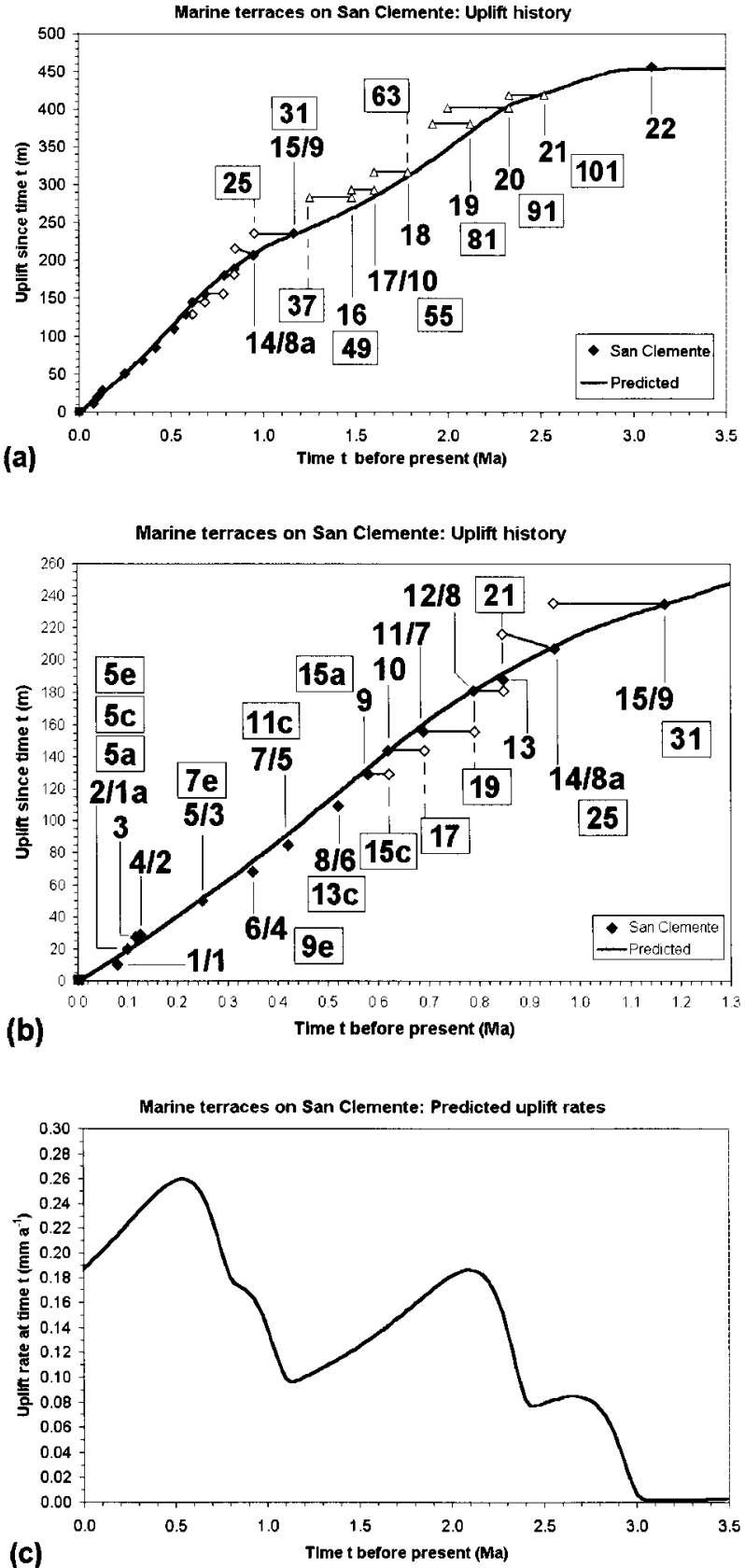

(c)

Fig. 23. (a) Observed and predicted uplift history for San Clemente. (b) Enlargement of (a), showing the Middle and Late Pleistocene in greater detail. (c) Predicted variation in uplift rate. Predictions use $\mathrm{z}_{\mathrm{b}}=16 \mathrm{~km}, \mathrm{z}_{\mathrm{i}}=26 \mathrm{~km}, \mathrm{u}=20^{\circ} \mathrm{C} \mathrm{km}^{-1}, \Delta \mathrm{T}_{\mathrm{el}}=-6.0^{\circ} \mathrm{C}$, $\Delta \mathrm{T}_{\mathrm{e} 2}=-4.7^{\circ} \mathrm{C}, \Delta \mathrm{T}_{\mathrm{e} 3}=-7.3^{\circ} \mathrm{C}, \Delta \mathrm{T}_{\mathrm{e} 4}=-5.5^{\circ} \mathrm{C}$, and $\Delta \mathrm{T}_{\mathrm{e} 5}=-6.2^{\circ} \mathrm{C}$. Terrace numbers and altitude data are from Lawson (1893), Muhs \& Szabo (1982) and Muhs (1983). Terraces are labelled as designated by Lawson (1893), followed by numbers from the modern notation where assigned. Middle Pleistocene and younger terraces are assumed to have formed at global sea-levels estimated for each oxygen isotope stage by Westaway (1996), uplift being calculated relative to these initial levels.

the sense of plate motions. However, Arger et al. (2000) have pointed out that whenever one has in the past observed uplift in any region known to be a plate boundary zone, it has seemed natural to try to explain this uplift as a result of plate motions, but it may in-
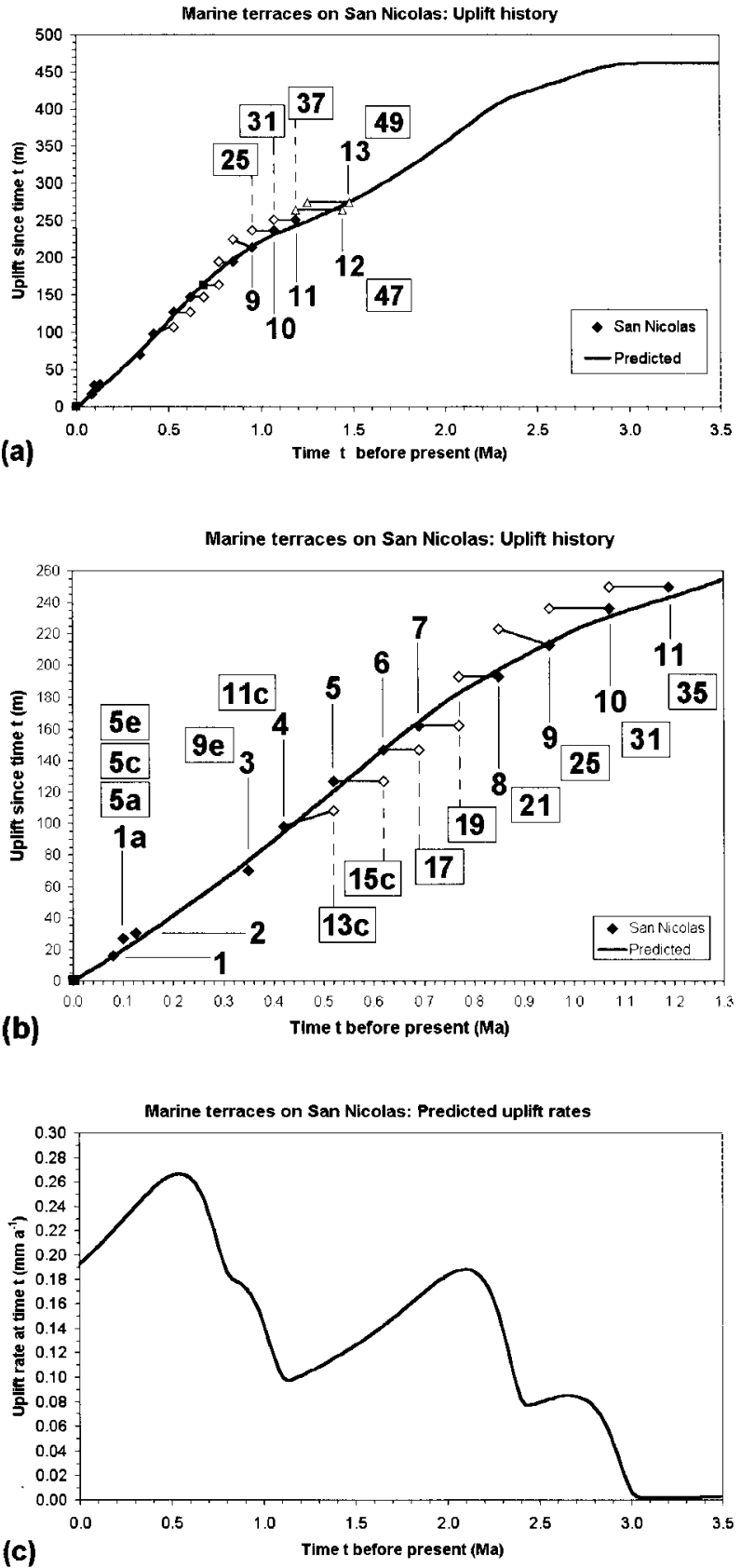

Fig. 24. (a) Observed and predicted uplift history for San Nicolas. (b) Enlargement of (a), showing the Middle and Late Pleistocene in greater detail. (c) Predicted variation in uplift rate. Predictions use $\mathrm{z}_{\mathrm{b}}=16 \mathrm{~km}, \mathrm{z}_{\mathrm{i}}=26 \mathrm{~km}, \mathrm{u}=20^{\circ} \mathrm{C} \mathrm{km} \mathrm{km}^{-1}, \Delta \mathrm{T}_{\mathrm{e} 1}=-6.0^{\circ} \mathrm{C}, \Delta \mathrm{T}_{\mathrm{e} 2}=$ $-4.7^{\circ} \mathrm{C}, \Delta \mathrm{T}_{\mathrm{e} 3}=-7.4^{\circ} \mathrm{C}, \Delta \mathrm{T}_{\mathrm{e} 4}=-5.8^{\circ} \mathrm{C}$, and $\Delta \mathrm{T}_{\mathrm{e} 5}=-6.3^{\circ} \mathrm{C}$. Terrace numbers and altitude data are from sources cited in the text. Uplift calculations follow the procedure used for Fig. 23.

stead reflect the same atectonic uplift process as has been interpreted elsewhere. San Clemente, discussed earlier, highlights this point. It follows that, in other plate boundary zone regions also, the surface uplift may be unrelated to the plate boundary processes 
that are occurring but may instead be forced by surface processes as in the regions - already considered that are not in plate boundary zones. As Arger et al. (2000) noted, this possibility may be tested by comparing the observed timing of uplift with timings of changes in the sense and rate of plate motions known independently - and with the timings of changes in rates of uplift that - from the present study - seem characteristic of regions outside plate boundary zones.

For instance, in western Turkey, the first region within a plate boundary zone where atectonic surface uplift was recognised (Westaway, 1993a, 1994), up to $\sim 500 \mathrm{~m}$ of post-Miocene uplift is marked by largescale gorge incision (e.g., Hamilton \& Strickland, 1841; Ozaner, 1992; Westaway, 1993a; RichardsonBunbury, 1996; Kuzcuoğlu, 1996). Similar incision indicates that many plate interior regions have also uplifted by hundreds of metres during the Neogene and Quaternary, but the timing is not well resolved. Examples include: southern and eastern Africa (e.g., Du Toit, 1933; King 1955; Bond, 1978; Partridge \& Maud, 1987; Veldkamp, 1996; Partridge, 1998); the Arabian platform, including southeastern Turkey (Arger et al., 2000) and western Iraq (Tyracek, 1987); and the Colorado Plateau (e.g., McKee \& McKee, 1972; Lucchitta, 1979) where McQuarrie \& Chase (2000) have recently argued that the surface uplift must have been caused by inward lower-crustal flow from beneath surrounding regions. De Sitter (1952), Flint (1957), Holmes (1965), Damon (1971), Eyles (1996), and Bridgland \& Maddy (2002) document more examples.

\section{Discussion}

In all localities considered, the observed uplift histories are well-explained as consequences of forcing of lower-crustal flow with the suggested chronologies. Localities show increased uplift rates in the Late Pliocene, caused by intensified forcing at $\sim 3.1$ and $\sim 2.5 \mathrm{Ma}$, followed by a decrease, then a renewed increase in the Middle Pleistocene caused by further intensifications at $\sim 1.2$ and $\sim 0.9 \mathrm{Ma}$. Many localities examined, notably Maastricht (Fig. 5c), the lower Rhine below Cologne (Fig. 6), the Most Basin (Fig. 11c), Reading (Fig. 13c), elsewhere along the Thames (Fig. 12; also Maddy, 1997), and Amiens (Fig. 15c), plus others mentioned (including Vichy and southern Australia: see Westaway, 2001; plus Prague), have had typical uplift rates of $\sim 0.07 \mathrm{~mm} \mathrm{a}^{-1}$ during the Middle-Late Pleistocene. Some of these localities uplifted faster in the latest Pliocene than in the Middle Pleistocene; others uplifted less quickly in response to this earlier forcing. This variability presumably reflects different geometries of lower-crustal flow due to the different amplitudes and periodicities of forcing at these different stages.

In many of the localities considered, other explanations have been proposed for the observed uplift, which regard it as having some local cause, such as an active fault zone running through the region. Often, as with the Channel Islands example already discussed, there is no independent evidence for this hypothetical local cause other than the uplift itself. Westaway (2001) discussed at length the history of local explanations for the uplift of the Rhenish Massif. Rather than listing a longer series of ad hoc explanations here, each applicable to a single locality, I simply repeat the point that the observed similarities in timing and uplift rates favour a common explanation, and the observed timings favour an explanation linked to Quaternary glaciations as is proposed in this study.

Another possibility, considered by Westaway et al. (2002) and Westaway (2002a), is that the first phase of accelerated uplift, starting in the latest Pliocene, is not the result of forcing of lower-crustal flow: it is instead the isostatic response to increased rates of erosion. It is suggested that during the long period of climate stability before the latest Pliocene, land surfaces became typically covered by a thick weathered layer or "regolith", which was stabilised by the presence of vegetation. Following the initial deterioration in climate at $\sim 3.1 \mathrm{Ma}$, the reduction in vegetation cover would be expected to result in the relatively rapid erosion of this layer, avoiding any inconsistency with the observation of low present-day erosion rates in the present study regions. This removal of material would reduce the pressure at the base of the brittle layer, whereupon the resulting inflow of lower crust could sustain surface uplift. The existence of this different mechanism provides a natural explanation for the lack of correlation - already noted - between amounts of uplift in a given region during the latest Pliocene and Middle-Late Pleistocene uplift phases. The calculations by Westaway (2002a, b) show that the amount of surface uplift that results on a given time scale following an increase in erosion rates may exceed many times the thickness of the layer of material eroded: under the resulting non-steadystate conditions, erosion can thus cause crustal thickening. Furthermore, these calculations indicate that the form of the uplift response following increased rates of erosion is very similar to that from cyclic surface loading (Fig. 1): thus resulting in no inconsistency with the present set of modelling results. Zhang et al. (2001) suggested a similar global effect of climate on erosion rates in the Late Pliocene, but 
much of their supporting evidence for its timing was not well constrained.

Several studies (e.g., McKenzie, 1984; LithgowBertollini \& Silver, 1998) have instead proposed that 'epeirogenic' surface uplift (i.e., regional-scale uplift of the Earth's surface in localities which are distant from plate boundaries) is caused by mantle plumes: as the isostatic response to the heating effect of the thermal anomaly in the plume stem and to the intrusion of igneous rocks into the lower crust. However, fluid dynamical simulations now indicate that mantle plumes affect regions with a diameter of $\sim 1000 \mathrm{~km}$ (e.g., White \& McKenzie, 1995), and do not exist on the variety of scales (both larger and smaller) which would be required to support all the instances of surface uplift documented in this study and its references. Furthermore, the observation that uplift rates world-wide have increased in the Quaternary would require, given this explanation, a global increase in mantle plume activity in the Quaternary. If one were to argue that this increase occurred coincidentally at the time of intensified glaciation, then there would be no way to develop this view into a testable hypothesis. If instead one were to argue that this timing relationship was due to cause and effect, then one would need to identify a mechanism by which either ice loading can cause the vigour of mantle convection to increase, or an increase in vigour of mantle convection can cause glaciation. As no such link has ever been suggested in either direction, it seems appropriate instead to explore the alternative general model summarised in Fig. 1.

Although some people have long argued that to form long-term terrace staircases (as in Figs. 4, 6, 10, 12,14 , and 16 ) requires uplift relative to sea level, others (e.g., Kiden \& Tornqvist, 1998) have disputed this point. However, the argument that if the land surface were not uplifting, river gravels will become repeatedly aggraded and incised at similar levels during successive climate cycles, appears unanswerable. This creates complex, scrappy, deposits, quite unlike ordered terrace staircases. This effect is illustrated by the Early Pleistocene gravels near the North Sea coast of southeast England (e.g., Bridgland \& Allen, 1996; Westaway et al., 2002), which formed when this region was neither uplifting nor subsiding significantly. Another example is Rhine Main Terrace 1 (Figs. 6 and 7), which apparently has an internal 'layer cake' stratigraphy in some localities and a 'cut and fill' stratigraphy in others, and developed over many climate cycles at a time of slow uplift (Fig. 7c) (Westaway, 2001). It is hoped that the point, that development of river terrace staircases with the spatial scale, altitude range, and age span of the examples present- ed here requires surface uplift, can now be regarded as settled.

It is of interest to contrast the different dating methods for marine and river terraces. Most constraints come from pollen assemblages and magnetostratigraphy for river terraces but from amino acid and uranium series dating for marine terraces. Because neither amino acid nor uranium series methods work beyond $\sim 0.3-0.5 \mathrm{Ma}$, the younger parts of marine terrace sequences can be well-dated but age control on their older parts may be completely lacking. In contrast, the sequence of magnetic polarity reversals in the Matuyama chron means that distinctive magnetostratigraphic records can be obtained from the Early Pleistocene: indeed, in Figs. 5 and 11 much of the Early Pleistocene appears better constrained than the Middle Pleistocene. The realisation that marine and river terrace deposits indicate equivalent uplift histories, despite the different forms of age constraints, suggests that future co-ordinated studies of both types of deposit in adjacent localities may yield better control than if either is studied separately.

The Huanghe terrace sequence (Figs. 19 and 20) provides an important test of the proposed model. As already noted, the greater time lag between the start of each phase of forcing and the resulting uplift response is well-explained by the greater thickness of lower crust in this region, given the greater overall crustal thickness and the presence of mantle lithosphere of normal thickness. This time lag is determined by the time required for heat flow perturbations to diffuse across the lower-crustal layer, and so will increase with thickness of this layer (Westaway, 2001). Another test is provided by the magnitude of the uplift response, which is much greater than any other locality. The logic behind the physical model (Fig. 1) indicates that the greater the difference in Moho temperature, between a region and its surroundings, the faster the uplift will be. Heat conduction across the extra $\sim 15 \mathrm{~km}$ of crust beneath this region will raise the Moho temperature by $\sim 200^{\circ} \mathrm{C}$, enhancing the temperature contrast relative to crust of normal thickness and so facilitating a higher uplift rate. Due to length limitations, no attempt is made here to test whether the lower crust has a low enough viscosity to allow it to flow fast enough from surrounding localities to maintain the required crustal thickening rate, for this locality or any other: except the tests for the Rhenish Massif already mentioned.

The extra crustal thickness beneath central Tibet means an even hotter Moho, implying even faster uplift, possibly as much as $\sim 1 \mathrm{~km}$ since the Middle Pliocene. Past international studies have argued that the uplift of Tibet was concentrated earlier, and it is 
now either uplifting slowly (e.g., Westaway, 1995), or possibly even subsiding (e.g., England, 1993). In contrast, many Chinese studies have argued using biostratigraphic evidence that the uplift of Tibet has been concentrated in the Plio-Quaternary (e.g., Yang, $1986 ; \mathrm{Li}, 1991)$. It now appears possible that this plateau has experienced its fastest uplift since the Middle Pliocene, although it was undoubtedly already several kilometres high by then.

Many people (e.g., Ruddiman \& Raymo, 1988) have argued that increasing relief of the Earth's surface has contributed to global cooling. Like Westaway (2001), this study thus raises the possibility of a hitherto unknown global coupling mechanism linking crustal deformation, surface uplift, and climate change. It suggests that low-amplitude fluctuations in sea-level in Miocene time caused net flow of crust to beneath the land, which slightly increased the mean altitude of the Earth's surface. This increase in altitude added to whatever global cooling was occurring independently, facilitating growth of ice sheets and the associated increase in amplitude of sea-level variations. The lower-crustal flow induced by these loading variations added to the increase in surface relief, which led to further global cooling, which further amplified the sea-level variations, which further affected the relief. The resulting positive feedback loop suggests that this process and its effects may intensify until they are ultimately countered by the increasing effective viscosity of the lower crust in areas of atectonic crustal thinning. However, other limiting mechanisms also exist (see, e.g., Westaway, 1995; Mitchell \& Westaway, 1999), so this ultimate limit may not be achievable.

As was mentioned earlier, many river terrace sequences indicate Middle-Late Pleistocene uplift rates of $\sim 0.07 \mathrm{~mm} \mathrm{a}^{-1}$, and become indistinct if rates are lower $\left(<\sim 0.03 \mathrm{~mm} \mathrm{a}^{-1} ;\right.$ Fig. $\left.7 \mathrm{c}\right)$. However, if rates substantially exceed $\sim 0.07 \mathrm{~mm} \mathrm{a}^{-1}$, terrace sequences also become less clear. This is indicated by the Middle Pleistocene records from the Seine (uplift rate up to $\sim 0.12 \mathrm{~mm} \mathrm{a}^{-1}$; Fig. $18 \mathrm{c}$; terrace record difficult to interpret) and middle Rhine (uplift rate up to $0.23 \mathrm{~mm}$ $\mathrm{a}^{-1}$; Fig. 7c; terrace record often non-existent, as in Fig. 8), and the Early Pleistocene record from the middle Thames (uplift rate up to $\sim 0.16 \mathrm{~mm} \mathrm{a}^{-1}$; Fig. $13 \mathrm{c}$ ), which is poor compared with the contemporaneous record from the Maas (uplift rate up to $\sim 0.06$ $\mathrm{mm} \mathrm{a}^{-1}$; Fig. $5 \mathrm{c}$ ). A possible explanation is that when uplift rates are high, greater relief develops during the phase of incision at the start of the next climate cycle, after a given terrace has aggraded. As a result, slope processes may be fast enough to remove the material forming each terrace before the next one has time to form. The idea that these limitations lead to an optimum uplift rate for river terrace formation was, of course, proposed long ago using numerical simulations (e.g., Veldkamp \& Vermeulen, 1989); it now appears well-supported by direct evidence.

The preponderance of Middle-Late Pleistocene uplift rates of $\sim 0.07 \mathrm{~mm} \mathrm{a}^{-1}$ may be a selection bias effect, arising because people tend to study river terraces where they are clearest, which (as already discussed) seems to require rates of this order. Alternatively, it may be indicating the most characteristic rate of lower-crustal flow in response to the typical magnitude of cyclic loading in the Middle-Late Pleistocene. A related point concerns the Middle-Late Pleistocene uplift rates of the small islands (peak: $\sim 0.27 \mathrm{~mm} \mathrm{a}^{-1}$; time-average: $\sim 0.24 \mathrm{~mm} \mathrm{a}^{-1}$; Figs. $23 \mathrm{c}$ and $24 \mathrm{c}$ ), which are $\sim 3$ times faster than for the river terraces. The scale of these islands means that their uplift may well not be isostatically compensated, being instead supported by the mantle lithosphere and so unaccompanied by a lower-crustal 'root'. If so, unlike the much larger-scale river terrace localities, surface uplift rates will equal crustal thickening rates. However, the ratio of crustal thickening rate to surface uplift rate is $\sim 6: 1$ for conventional Airy isostasy (e.g., Westaway, 1995), roughly double the $\sim 3: 1$ ratio observed here. Exploring the physical significance of this difference is beyond the scope of this study.

\section{Conclusions}

Long-term river terrace sequences indicate a global increase in uplift rates in the Late Pliocene, followed by a lull then a renewed increase around the EarlyMiddle Pleistocene boundary. Many regions have uplifted by several hundred metres on this time scale. Terrace sequences appear clearest when regions are uplifting at rates of $\sim 0.07 \mathrm{~mm} \mathrm{a}^{-1}$ : a rate frequently observed during the Middle and Late Pleistocene. It is suggested that this uplift pattern has resulted from thickening of the continental crust caused by flow in the lower crust which has been induced by cyclic surface loading caused by growth and decay of ice sheets and the associated global sea-level fluctuations. The observed uplift histories are modelled using a technique which incorporates increases in the intensity of forcing of this process caused by step changes in the intensity of glaciations starting at $\sim 3.1, \sim 2.5, \sim 1.2$, and $\sim 0.9 \mathrm{Ma}$.

\section{Acknowledgements}

I thank Darrel Maddy, David Bridgland, Meindert Van den Berg, Rob Van der Voo, Jaroslav Tyracek, and 
Tom Veldkamp for helpful discussions and correspondence. Wolfgang Jacoby and an anonymous reviewer provided thoughtful and constructive reviews.

This paper contributes to IGCP 449 (Global correlation of Late Cenozoic fluvial deposits).

\section{References}

Ahnert, F., 1970. Functional relationships between denudation, relief, and uplift in large mid-latitude drainage basins. American Journal of Science 268: 243-263.

Antoine, P., 1994. The Somme valley terrace system (northern France); A model of river response to Quaternary climatic variations since 800,000 B.P.. Terra Nova 6: 453-464.

Antoine, P., Lautridou, J.-P., Sommé, J., Auguste, P., Auffret, J.-P., Baize, S., Clet-Pellerin, M. , Coutard, J.P., Dewolf, Y., Dugué, O., Joly, F., Laignel, B., Laurent, M., Lavollé, M., Lebret, P., Lécolle, F., Lefebvre, D., Limondin-Lozouet, N., Munaut, A.V., Ozouf, J.C., Quesnel, F. \& Rousseau, D.-D., 1998. The Quaternary formations of north-west France: boundaries and correlations. Quaternaire 9: 227-241 (in French with English abstract).

Arger, J., Mitchell, J. \& Westaway, R., 2000. Neogene and Quaternary volcanism of south-eastern Turkey. In: Bozkurt, E.J.A. Winchester, J.A. \& Piper, J.D.A. (eds): Tectonics and Magmatism of Turkey and the Surrounding Area. Geological Society of London Special Publication 173: 459-487.

Atwater, T., 1987. Plate tectonic history of the northeast Pacific and western North America. In: Winterer, E.L., Hussong, D.M. \& Decker, R.W. (eds): The Eastern Pacific Ocean and Hawaii. The Geology of North America, vol. N. Geological Society of America (Boulder, Colorado): 21-72.

Bates, M.R., 1993. Quaternary aminostratigraphy in northwestern France. Quaternary Science Reviews 12: 793-809.

Bibus, E. \& Semmel, A., 1977. Über die Auswirkung quartärer Tektonik auf die altpleistozänen Mittelrhein Terrassen. Catena 4: 385-408.

Bond, G., 1978. Evidence for Late Tertiary uplift of Africa relative to North America, South America, Australia and Europe. Journal of Geology 86: 47-65.

Bridgland, D.R., 1994. The Quaternary of the Thames. Nature Conservancy Council (London): $441 \mathrm{pp}$.

Bridgland, D.R., 1995. The Quaternary sequence of the eastern Thames basin: Problems of correlation. In: Bridgland, D.R., Allen, P. \& Haggart, B.A. (eds): The Quaternary of the Lower Reaches of the Thames, Field Guide. Quaternary Research Association (Durham, England): 35-52.

Bridgland, D.R. \& Allen, P., 1996. A revised model for terrace formation and its significance for the early Middle Pleistocene terrace aggradations of north-east Essex, England. In: Turner, C. (ed.): The early Middle Pleistocene in Europe. Balkema (Rotterdam): 121-134.

Bridgland, D.R. \& Maddy, D., 2002. Global correlation of long Quaternary fluvial sequences. Netherlands Journal of Geosciences, this volume.

Brunnacker, K., Farrokh, F. \& Sidiropoulos, D., 1982a. Die altquatären Terrassen östlich der Niederrheinischen Bucht. Zeitschrift für Geomorphologie, Neue Folge, Supplement 42: 215-226 (in German with English summary).

Brunnacker, K., Löscher, M., Tillmanns, W. \& Urban, B., 1982b. Correlation of the Quaternary terrace sequence in the Lower Rhine valley and northern Alpine foothills of Central Europe. Quaternary Research 18: 152-173.

Damon, P.E., 1971. The relationship between Late Cenozoic vol- canism and tectonism and orogenic-epeiorogenic periodicity. In: Turekian, K.E. (ed.): The Late Cenozoic Glacial Ages. Yale University Press (New Haven, Connecticut): 15-35.

De Sitter, L.U., 1952. Pliocene uplift of Tertiary mountain chains. American Journal of Science 250: 297-307

Du Toit, A.L., 1933. Crustal movement as a factor in the geographical evolution of South Africa. South African Geographical Journal 16: 3-20.

Emery, K.O., 1958. Shallow submerged marine terraces of southern California. Geological Society of America Bulletin 69: 39-60.

England, P., 1993. Convective removal of thermal boundary layer of thickened continental lithosphere: a brief summary of causes and consequences with special reference to the Cenozoic tectonics of the Tibetan Plateau and surrounding regions. Tectonophysics 223: 67-73.

Eyles, N., 1996. Passive margin uplift around the North Atlantic region and its role in northern hemisphere late Cenozoic glaciation. Geology 24: 103-106.

Fielding, E., Isacks, B., Barazangi, M. \& Duncan, C., 1994. How flat is Tibet? Geology 22: 163-167.

Flint, R.F., 1957. Glacial and Pleistocene Geology. John Wiley \& Sons (London, England): 553 pp..

Gallois, R.W., 1965. British Regional Geology, The Wealden District, 4th edition. Her Majesty's Stationary Office (London, England): $101 \mathrm{pp}$.

Gilchrist, A.R., Summerfield, M.A. \& Cockburn, H.A.P., 1994. Landscape dissection, isostatic uplift, and the morphologic development of orogens. Geology 22: 963-966.

Gorsline, D.S. \& Teng, L.S.-Y., 1987. The California Continental Borderland. In: Winterer, E.L., Hussong, D.M. \& Decker, R.W. (eds): The Eastern Pacific Ocean and Hawaii, The Geology of North America, vol. N. Geological Society of America, (Boulder, Colorado): 471-487.

Hamilton, W.J. \& Strickland, H.E., 1841. On the geology of the western part of Asia Minor. Transactions of the Geological Society of London 6: 1-39.

Hilgen, F.J. 1991. Astronomical calibration of Gauss to Matuyama sapropels in the Mediterranean and implications for the Geomagnetic Polarity Time Scale. Earth and Planetary Science Letters 104: 226-244.

Holmes, A., 1965. Principles of Physical Geology, 2nd edition. Nelson (London, England): 1288 pp..

Illies, J.H., Prodehl, C., Schminke, H.-U. \& Semmel, A., 1979. The Quaternary uplift of the Rhenish Shield in Germany. Tectonophysics 61: 197-225.

Kaufman, P.S. \& Royden, L.H., 1994. Lower crustal flow in an extensional setting: Constraints from the Halloran Hills region, eastern Mojave Desert, California. Journal of Geophysical Research 99: 15723-15739.

Kiden, P. \& Törnqvist, T.E., 1998. Can river terrace flights be used to quantify Quaternary tectonic uplift rates? Journal of Quaternary Science 13: 573-574.

King, L.C., 1955. Pediplanation and isostacy: An example from South Africa. Quarterly Journal of the Geological Society of London 111: 353-359.

Klein, A., Jacoby, W. \& Smilde, P., 1997. Mining-induced crustal deformation in northwest Germany: modelling the rheological structure of the lithosphere. Earth and Planetary Science Letters 147: 107-123.

Kusznir, N.J. \& Park, R.G., 1984. Continental lithosphere strength: the critical role of lower crustal deformation. In: Dawson, J.B., Carswell, D.A. \& Wedepohl, K.H. (eds): The Nature of the Lower Continental Crust. Geological Society of London Special Publication 24: 79-93.

Kuzcuoglu, C., 1996. River response to Quaternary tectonics with 
examples from northwestern Anatolia. In: Lewin, J. (ed.): Mediterranean Quaternary River Environments. Balkema (Rotterdam): 45-53.

Larson, K.M., 1993. Application of the Global Positioning System to crustal deformation measurements 3 . Result from the southern California borderlands. Journal of Geophysical Research 98: 21,713-21,726.

Lautridou, J.-P., Auffret, J.-P., Baltzer, A., Clet, M., Lécolle, F., Lefebvre, D., Lericolais, G., Roblin-Jouve, A., Balescu, S., Carpentier, G., Descombes, J.-C., Occhietti, S. \& Rousseau, D.-D., 1999. The river Seine, the river Manche. Bulletin de la Société Géologique de France 170: 545-558 (in French with English summary).

Lawson, A.C., 1893. The post-Pliocene diastrophism of the coast of southern California. University of California Publications, Bulletin of the Department of Geology 1: 115-160.

Legg, M.R., 1991. Developments in understanding the tectonic evolution of the California Continental Borderland. In: From Shoreline to Abyss. Society of Economic Paleontologists and Mineralogists Special Publication 46: 291-312.

$\mathrm{Li}$ Jujun, 1991. The environmental effects of the uplift of the Qinghai-Xizang plateau. Quaternary Science Reviews 10: 479-483.

Li Jujun, Fang Xiaomin, Van der Voo, R., Zhu Junjie, MacNiocaill, C., Ono, Y., Pan Baotian, Zhong Wei, Wang Jianli, Sasaki, T., Zhang Yutian, Cao Jixiu, Kang Shichuang \& Wang Jianming, 1997a. Magnetostratigraphic dating of river terraces: Rapid and intermittent incision by the Yellow River of the northeastern margin of the Tibetan Plateau during the Quaternary. Journal of Geophysical Research 102: 10121-10132.

Li Jujun, Fang Xiaomin, Van der Voo, R., Zhu Junjie, MacNiocaill, C., Cao Jixiu, Zhong Wei, Chen Huailu, Wang Jianli, Wang Jianming \& Zhang Yiechun, 1997b. Late Cenozoic magnetostratigraphy (11-0 Ma) of the Dongshanding and Wangilashan sections in the Longzhong Basin, western China. Geologie en Mijnbouw 86: 121-134.

Lithgow-Bertelloni, C. \& Silver, P.G., 1998. Dynamic topography, plate driving forces, and the African superswell. Nature 395: 269-272.

Lucchitta, I., 1979. Late Cenozoic uplift of the southwestern Colorado Plateau and adjacent lower Colorado River region. Tectonophysics 61: 63-95.

Lüttig, G. \& Meyer, K.-D., 1975. Geological history of the River Elbe, mainly of its lower course. In: Macar, P. (ed.): L'évolution quaternaire des bassins fluviaux de la mer du nord méridionale. Centenaire de la Société géologique de Belgique (Liège, Belgium): 1-19.

Ma Xingyuan, Deng Qidong, Wang Yipeng \& Liu Hefu, 1982. Cenozoic graben systems in north China. Zeitschrift für Geomorphologie, Neue Folge, Supplement 42: 99-1 16.

Maddy, D., 1997. Uplift-driven valley incision and river terrace formation in southern England. Journal of Quaternary Science 12: 539-545.

Maddy, D., 1998. Reply: Can river terrace flights be used to quantify Quaternary tectonic uplift rates? Journal of Quaternary Science 13: 574-575.

Maddy, D. \& Bridgland, D.R., 2000. Accelerated uplift resulting from Anglian glacioisostatic rebound in the Middle Thames valley, UK?: Evidence from the river terrace record. Quaternary Science Reviews 19: 1581-1588.

Maddy, D., Bridgland, D.R. \& Green, C.P., 2000. Crustal uplift in southern England: Evidence from the river terrace records. Geomorphology 33: 167-181.

Maddy, D., Bridgland, D.R. \& Westaway, R., 2001. Uplift-driven valley incision and climate-controlled river terrace development in the Thames valley, UK. Quaternary International 79:23-36.
McKee, E.D. \& McKee, E.H., 1972. Pliocene uplift of the Grand Canyon region - Time of drainage adjustment. Geological Society of America Bulletin 83: 1923-1932.

McKenzie, D., 1984. A possible mechanism for epeirogenic uplift. Nature 307: 616-618.

McQuarrie, N. \& Chase, C., 2000. Raising the Colorado Plateau. Geology 28: 91-94.

Milliman, J.D. \& Syvitski, J.P.M., 1992. Geomorphic/tectonic control of sediment discharge to the ocean: the importance of small mountainous rivers. Journal of Geology 100: 525-544.

Mitchell, J. \& Westaway, R., 1999. Chronology of Neogene and Quaternary uplift and magmatism in the Caucasus: Constraints from $\mathrm{K}-\mathrm{Ar}$ dating of volcanism in Armenia. Tectonophysics 304 : 157-186.

Moffat, A.J. \& Catt, J.A., 1986. A re-examination of the evidence for a Plio-Pleistocene marine transgression on the Chiltern Hills. III. Deposits. Earth Surface Processes and Landforms 11: 233247.

Molnar, P. \& England, P., 1990. Late Cenozoic uplift of mountain ranges and global climate change: chicken or egg. Nature 346 : 29-34.

Molnar, P., England, P. \& Martinod, J., 1993. Mantle dynamics, uplift of the Tibetan plateau, and the Indian monsoon. Reviews of Geophysics 31: 357-396.

Morzadec-Kerfourn, M.T., 1997. Dinoflagellate cysts and the palaeoenvironment of Late-Pliocene Early-Pleistocene deposits of Brittany, north-west France. Quaternary Science Reviews 16: 883-898.

Muhs, D.R., 1983. Quaternary sea-level events on northern San Clemente island, California. Quaternary Research 20:322-341.

Muhs, D.R., 1985. Amino acid age estimates of marine terraces and sea levels on San Nicolas Island, California. Geology 13: 5861 .

Muhs, D.R. \& Szabo, B.J., 1982. Uranium-series age of the Eel Point terrace, San Clemente island, California. Geology 10: 2326.

Muhs, D.R., Kennedy, G.L. \& Rockwell, T.K., 1994. Uranium-series ages of marine terrace corals from the Pacific coast of North America and implications for last-interglacial sea level history. Quaternary Research 42: 72-87.

Mudelsee, M. \& Schulz, M., 1997. The Mid-Pleistocene climate transition: onset of 100 ka cycle lags ice volume build-up by 280 ka. Earth and Planetary Science Letters 151: 117-123.

Murray-Wallace, C.V., Belperio, A.P., Cann, J.H., Huntley, D.J. \& Prescott, J.R., 1996. Late Quaternary uplift history, Mount Gambier region, South Australia. Zeitschrift für Geomorphologie, Neue Folge, Supplement 106: 41-56.

Olmsted, F.H., 1958. Geologic reconnaissance of San Clemente Island, California. U.S. Geological Survey Bulletin 1071-B: 1-68.

Ozaner, F.S., 1992. Detecting the polycyclic drainage evolution in Kula region (western Turkey) using aerial photographs. ITC Journal 1992-3: 249-253.

Partridge, T.C., 1998. Of diamonds, dinosaurs and diastrophism: 150 million years of landscape evolution in southern Africa. South African Journal of Geology 101: 167-184.

Partridge, T.C. \& Maud, R.R., 1987. Geomorphic evolution of southern Africa since the Mesozoic. South African Journal of Geology 90: 179-208.

Pirazzoli, P.A., Radtke, U., Hantoro, W.S.C., Jouannic, C., Hoang, C.T., Causse, C. \& Borel Best, M., 1991. Quaternary raised coral-reef terraces on Sumba Island, Indonesia. Science 252: 1834-1836.

Präger, F., 1966. Zur Kenntnis der rezenten Tektonik im Gebiet östlich von Pirna auf der Grundlage pleistozängeologischer Untersuchungen. Geologie (Berlin) 15: 79-96. 
Quitzow, H.W. \& Thome, K.N., 1975. Les terrasses du Rhin de Sinzig et Cologne. Pléistocène ancien de la cuvette de l'Erft. In: Macar, P. (ed.): L'évolution quaternaire des bassins fluviaux de la mer du nord méridionale. Centenaire de la Société géologique de Belgique (Liège, Belgium): 308-318.

Richardson-Bunbury, J.M., 1996. The Kula volcanic field, western Turkey: the development of a Holocene alkali basalt province and the adjacent normal-faulting graben. Geological Magazine 133: $275-283$.

Rose, J., Whiteman, C.A., Allen, P. \& Kemp, R.A., 1999. The Kesgrave Sands and Gravels: 'pre-glacial' Quaternary deposits of the River Thames in East Anglia and the Thames valley, Proceedings of the Geologists' Association 110:93-116.

Ruddiman, W.F. \& Raymo, M.E., 1988. Northern hemisphere climate régimes during the past $3 \mathrm{Ma}$ : Possible tectonic connections. Philosophical Transactions of the Royal Society of London, Series B 318: 411-430.

Schumm, S.A., Dumont, J.F. \& Holbrook, J.M., 2000. Active tectonics and Alluvial Rivers. Cambridge University Press (Cambridge, England): 290 pp.

Schwalbach, J.R. \& Gorsline, D.S., 1985. Holocene sediment budgets for the basins of the California continental borderland. Journal of Sedimentary Petrology 55: 829-842.

Semmel, A., 1991. Neotectonics and geomorphology in the Rhenish massif and the Hessian basin. Tectonophysics 195: 291-297.

Shackleton, N.J., Berger, A. \& Peltier, W.R., 1990. An alternative astronomical calibration of the lower Pleistocene timescale based on ODP site 677. Transactions of the Royal Society of Edinburgh, Earth Sciences 81: 251-261.

Shackleton, R.M. \& Chang Chengfa, 1988. Cenozoic uplift and deformation of the Tibetan Plateau: the geomorphological evidence, Philosophical Transactions of the Royal Society of London, Series A 327: 365-377.

Sibson, R.H., 1982. Fault zone models, heat flow, and the depth distribution of earthquakes in the continental crust of the United States. Bulletin of the Seismological Society of America 72: 151163.

Smith, W.S.T., 1898. A geological sketch of San Clemente island, U.S. Geological Survey 18th Annual Report, part 2: 459-496.

Smith, W.S.T., 1900. A topographic study of the islands of southern California, University of California Publications, Bulletin of the Department of Geology 2: 179-230.

ten Brink, U.S., Jie Zhang, Brocher, T.M., Okaya, D.A., Klitgord, K.D. \& Fuis, G., 2000. Geophysical evidence for the evolution of the California Inner Borderland as a metamorphic core complex. Journal of Geophysical Research 105: 5835-5857.

Tyracek, J., 1987. Terraces of the Euphrates River. Sbornik Geologickych Ved Anthropozoikum 18: 185-202.

Tyracek, J., 1995. Stratigraphy of the Ohre River terraces in the Most Basin. Sbornik geologickych Ved. Anthropozoikum 22: 141-157.

Valentine, J.W. \& Veeh, H.H., 1969. Radiometric ages of Pleistocene terraces from San Nicolas Island, California. Geological Society of America Bulletin 80, 1415-1418.

Van den Berg, M.W., 1996. Fluvial sequences of the Maas: a $10 \mathrm{Ma}$ record of neotectonics and climate change at various time-scales. Ph.D.Thesis, University of Wageningen, The Netherlands.

Van den Berg, M.W, \& van Hoof, T., 2001. The Maas terrace sequence at Maastricht, SE Netherlands: evidence for $200 \mathrm{~m}$ of late Neogene and Quaternary surface uplift. In: Maddy, D., Macklin, M.G. \& Woodward, J.C. (eds), River Basin Sediment Systems: Archives of Environmental Change. Balkema (Abingdon, England): 45-86

Vedder, J.G. \& Norris, R.M., 1963. Geology of San Nicolas island, California. U.S. Geological Survey Professional Paper 369: 65 pp. Veeh, H.H., 1966. $\mathrm{Th}^{230} / \mathrm{U}^{238}$ and $\mathrm{U}^{234} / \mathrm{U}^{238}$ ages of Pleis- tocene high sea level stand. Journal of Geophysical Research 71: 3379-3386.

Veldkamp, A., 1992. A 3-D model of Quaternary terrace development, simulations of terrace stratigraphy and valley asymmetry: A case study for the Allier terraces (Limagne, France). Earth Surface Processes and Landforms 17: 487-500.

Veldkamp, A., 1996. Late Cenozoic landform development in East Africa: The role of near base level planation within the dynamic etchplanation concept. Zeitschrift für Geomorphologie, Neue Folge, Supplement 106: 25-40.

Veldkamp, A. \& Vermeulen, S.E.J.W., 1989. River terrace formation, modelling, and 3-D graphical simulation. Earth Surface Processes and Landforms 14: 641-654.

Ward, S.N. \& Valensise, G., 1996. Progressive growth of San Clemente Island, California, by blind thrust faulting: Implications for fault slip partitioning in the California Continental Borderland. Geophysical Journal International 126: 712-734.

Wehmiller, J.F., Lajoie, K.R., Kvenvolden, K.A., Peterson, E., Belknap, D.F., Kennedy, G.L., Addicott, W.O., Vedder, J.G. \& Wright, R.W., 1977, Correlation and chronology of Pacific coast marine terrace deposits of continental United States by fossil amino acid stereochemistry: Technique evaluation, relative ages, kinetic model ages, and geologic implications. U.S. Geological Survey Open-File Report 77-680: 196 pp.

Westaway, R., 1993a. Neogene evolution of the Denizli region of western Turkey. Journal of Structural Geology 15: 37-53.

Westaway, R., 1993b. Quaternary uplift of southern Italy. Journal of Geophysical Research 98: 21741-21772.

Westaway, R., 1994. Evidence for dynamic coupling of surface processes with isostatic compensation in the lower crust during active extension of western Turkey. Journal of Geophysical Research 99: 20203-20223.

Westaway, R., 1995. Crustal volume balance during the IndiaEurasia collision and altitude of the Tibetan plateau: a working hypothesis. Journal of Geophysical Research 100: 15173-15194.

Westaway, R., 1996. Quaternary elevation change in the Gulf of Corinth of central Greece. Philosophical Transactions of the Royal Society of London, Series A 354: $1125-1164$.

Westaway, R., 1998. Dependence of active normal fault dips on lower-crustal flow regimes. Journal of the Geological Society of London 155: 233-253.

Westaway, R., 2001. Flow in the lower continental crust as a mechanism for the Quaternary uplift of the Rhenish Massif, northwest Europe. In: Maddy, D., Macklin, M.G. \& Woodward, J.C. (eds), River Basin Sediment Systems: Archives of Environmental Change. Balkema (Abingdon, England): 87-167.

Westaway, R., 2002a. Geomorphological consequences of weak lower continental crust, and its significance for river valley evolution. Netherlands Journal of Geosciences, this volume.

Westaway, R., 2002b. The Quaternary evolution of the Gulf of Corinth, central Greece: coupling between surface processes and flow in the lower continental crust. Tectonophysics, 348: 269-318.

Westaway, R., Maddy \& D., Bridgland, D.R., 2002. Flow in the lower continental crust as a mechanism for the Quaternary uplift of southeast England: constraints from the Thames terrace record. Quaternary Science Reviews, 21:559-603.

Whipple, K.X., Kirby, E. \& Brocklehurst, S.H., 1999. Geomorphic limits to climate-induced increases in topographic relief. Nature 401: 39-43.

White R.S. \& McKenzie D., 1995. Mantle plumes and flood basalts. Journal of Geophysical Research 100: 17,543-17,585.

Worssam, B.C., 1963. Geology of the country around Maidstone: Memoir for 1:50,000 scale geological map sheet 288 (England and Wales). Her Majesty's Stationery Office (London, England): $152 \mathrm{pp}$. 
Yang Zunyi, 1986. The Cainozoic. In: Yang Zunyi, Cheng Yuqi \& Wang Hongzhen (eds): The Geology of China. Clarendon Press (Oxford, England): 168-185.

Zaruba, Q., Bucha, V. \& Lozek, V., 1977. Significance of the Vltava terrace system for Quaternary chronostratigraphy, Rozpravy
Ceskoslovenske Akademie Ved, Rada Matematickych a Prirodnich Ved 87 (4): 1-89.

Zhang Peizhen, Molnar, P. \& Downs, W.B., 2001. Increased sedimentation rates and grain sizes $2-4 \mathrm{Myr}$ ago due to the influence of climate change on erosion rates. Nature 410: 891-897. 